\title{
Biocatalytic Approaches Using Lactulose: End Product Compared with Substrate
}

\author{
Sara C. Silvério, Eugénia A. Macedo, José A. Teixeira, and Lígia R. Rodrigues
}

\begin{abstract}
Lactulose is a lactose-based carbohydrate with well-known prebiotic effect and recognized medical applications. Currently, the commercially available lactulose is chemically synthesized. Nevertheless, the process leads to low yields and high levels of by-products. Alternatively, lactulose can be produced by enzymatic synthesis, which provides a cleaner production under mild conditions. Two different enzymatic routes were reported for lactulose production. Lactulose can be obtained through hydrolysis and transfer reactions catalyzed by a glycosidase. Alternatively, lactulose can be produced by direct isomerization of lactose to lactulose catalyzed by cellobiose-2-epimerase. An interesting characteristic of lactulose is also its capacity to act as substrate in additional enzymatic synthesis which leads to the formation of attractive compounds, such as lactulose-based oligosaccharides and lactulose esters. Besides increasing the interest and potential of lactulose, these lactulose-based compounds can also offer new and promising functionalities and applications. Herein, we review the enzymes involved in the synthesis of lactulose, as well as the reaction conditions and yields. The potential of different enzymes is discussed and it is shown that reaction conditions and composition of products depend on the type of enzyme and its microbial source. The conversion of lactulose into lactulose-based compounds is also covered, describing in detail the biocatalysts involved, the reaction conditions used, and the potential of the final products obtained.
\end{abstract}

Keywords: enzymatic synthesis, lactulose, lactulose ester, oligosaccharides, prebiotic

\section{Introduction}

Nowadays, society strongly demands safe foods that are also able to improve well-being, extend lifetime, and prevent the development of many diseases like cancer or cardiovascular problems. In this way, food is no longer faced as a simple source of energy and body-forming nutrients; it has gained also the role of supplying biologically active substances. Prebiotics are an example of bioactive substances, since by definition they are "a selective fermented ingredient that allows specific changes, both in the composition and/or activity of the gastrointestinal microflora that confers benefits upon host well-being and health" (Gibson and others 2004). Lactulose (4-O- $\beta$-D-galactopyranosyl-D-fructose) is in the group of the currently accepted prebiotics, together with other nondigestible oligosaccharides such as fructans and galactans (Gibson and others 2010). It is a synthetic disaccharide composed of fructose and galactose, linked through a $\beta-1,4$-glycosidic bond, with 0.48 to 0.62 times the sweetness of sucrose and 1.5 times that of lactose (Playne and Crittenden 2009). Since the 1950s, lactulose has been used as a medical drug in the treatment of encephalopathy and constipation both in humans and animals. Therefore, lactu-

MS 20160390 Submitted 11/3/2016, Accepted 13/5/2016. Authors C. Silvério, Teixeira, and Rodrigues are with CEB-Centre of Biological Engineering, Univ. do Minho, Campus de Gualtar, 4710-057 Braga, Portugal. Author A. Macedo is with LSRE-Laboratory of Separation and Reaction Engineering-Associate Laboratory LSRE/LCM, Faculdade de Engenharia, Univ. do Porto, Rua Dr. Roberto Frias, 4200-465 Porto, Portugal. Direct inquiries to author Silvério (E-mail: sarasilverio@ deb.uminho.pt) lose became known first as a medical product (Schumann 2002). Its benefits as prebiotic were only explored later when it became clear that prebiotic action can have noteworthy effects at the physiological level. Lactulose contribution to maintain or restore a healthy gut microbiota, through the promotion of growth and activity of beneficial bacteria over pathogenic species, has deserved an increasing attention, and lactulose is now considered an appropriate ingredient for the development of functional foods. Since it was the 1st commercially available prebiotic (Playne and Crittenden 2009), and its medical application was soon accepted, lactulose easily acquired a legal status (Schumann 2002) that facilitates its incorporation in foods. Lactulose is commonly consumed by groups of people with specific nutritional needs, such as infants, where it is incorporated in the preparation of formulas with the aim to stimulate the beneficial microflora (Nagendra and others 1995). Furthermore, lactulose can be included in cookies, chocolates, or yogurts, not only due to its prebiotic effect but also due to its taste improvement, texturizing, and stabilizing effects, and low caloric value (Schumann 2002). The activity of lactulose is not limited to the gastrointestinal tract; other areas of the body can suffer relevant direct or indirect gains. For example, lactulose intake can reduce the serum triacylglycerols (Vogt and others 2006), the incidence of ventilator-associated pneumonia (Zvonicek and others 2001), and the risk of cancer (Hennigan and others 1995), while the absorption of minerals such as calcium and magnesium (Seki and others 2007) is increased during its consumption. For all these reasons, the interest in lactulose has significantly increased, which is reflected in the extent of its production. Estimates point 
out that the total annual global production of lactulose has increased from 20,000 tons in 1994/1995 to 40,000 tons in 2004, and around 50,000 tons in 2009 (Playne and Crittenden 2009). Currently, the commercially available lactulose is exclusively obtained by chemical synthesis. However, the alternative synthesis by enzymatic route has gained increased attention in the last few decades. The ability of enzymes to convert substrates into specific products under mild conditions has been explored and there are several studies in the literature reporting the efficiency of different biocatalysts in the synthesis of lactulose. Furthermore, lactulose itself can be the substrate for enzymatic reactions to produce other interesting compounds such as lactulose-based oligosaccharides or lactulose esters, which have also potential for food applications. This review provides an overview on the catalysts, reaction conditions, and yields described for the enzymatic synthesis of lactulose, it also compiles the most relevant information about the production and potential of some lactulose-based compounds obtained by the enzymatic route.

\section{Lactulose Production}

Although lactulose does not occur naturally in raw milk, it can be obtained in small amounts from lactose isomerization during the conventional procedures of milk pasteurization. Lactulose formation takes place during the heating of milk and its content depends both on the temperature and heating time used in the process (Claeys and others 2001). Therefore, lactulose can be considered a thermal indicator of milk treatment (Marconi and others 2004; Manzi and Pizzoferrato 2013) with a practical application in the characterization of industrially processed milk (Morales and others 2000).

The commercial production of lactulose started in 1953 (Playne and Crittenden 2009) and, taking into account its production volume, it can be considered the most important lactose derivative (Hajek and others 2013). At an industrial level, lactulose is mainly produced by chemical synthesis. However, other alternative methodologies should be considered. Figure 1A illustrates the 3 possible methods known for the production of lactulose.

\section{Chemical synthesis}

Montgomery and Hudson (1930) were the 1st to report the synthesis of a new crystalline disaccharide ketose obtained from lactose. This ketose received the name lactulose and its formation occurred by heating a mixture of lactose and calcium hydroxide, at $35{ }^{\circ} \mathrm{C}$, for several hours. Since then, this process of lactulose production through lactose isomerization has been widely studied. The isomerization reaction occurs by the conversion of the glucose moiety from lactose into fructose (Aider and Halleux 2007). This transformation is commonly referred to as Lobry de Bruynvan Ekenstein rearrangement (Hajek and others 2013). Besides calcium hydroxide, other alkaline catalysts like sodium hydroxide (Zokaee and others 2002), magnesium oxide (Carobbi and others 1985), or triethylamine (Parrish 1970) have been described. The isomerization reaction requires important amounts of the alkaline catalysts, but low yields (around 20\%) and high levels of unwanted products are obtained due to both product degradation and occurrence of undesirable side reactions (Aider and Halleux 2007). Side products are also accountable for the typical brownish color observed in the reaction mixture. Consequently, cost-intensive and laborious purification processes are required to obtain lactulose with purity levels that can be accepted in more demanding applications, such as pharmaceutical or medical applications (Playne and Crittenden 2009). Sulfites and phosphates have also been em- ployed in lactose isomerization processes at high temperature (80 to $\left.100{ }^{\circ} \mathrm{C}\right)$ and high lactose content $(60 \%$ to $70 \% \mathrm{w} / \mathrm{v})$. These compounds have the advantage to prevent oxidation of disaccharides (Aider and Halleux 2007) and reduce the brown color of the mixture during isomerization. Some amphoteric electrolytes, like aluminum hydroxide or boric acid, can also be used to increase the isomeric conversion of lactose into lactulose (Kozempel and others 1995). It is described that complexing agents like borate and aluminate have the ability to shift the equilibrium toward lactulose formation, thus the lactulose yield can be significantly increased to $70 \%$ to $80 \%$ (Aider and Halleux 2007; Playne and Crittenden 2009). However, such reagents are difficult to remove from the reaction mixture. Furthermore, a very high ratio of borate-tosugar is needed to improve the lactulose yield, which increases the production costs and complicates even more the removal of the catalyst (Playne and Crittenden 2009). In order to aid the elimination of catalysts from the lactulose solution, a new group of substances was proposed, namely the heterogeneous catalysts. Calcium carbonated-based products (as in egg shell), zeolites, and sepiolite are some examples of these catalysts (Shukla and others 1985; Troyano and others 1996; Montilla and others 2005). The main advantage associated with the use of such compounds is their easy removal by centrifugation.

\section{Electroactivation synthesis}

Recently, a new methodology involving the electroisomerization of lactose has been introduced and described as a safe, economic, and reagentless approach to produce lactulose (Aider and Gimenez-Vidal 2012; Aït Aissa and Aïder 2013a). This methodology involves the use of an electroisomerization reactor which is divided into 3 different compartments: the cathodic compartment, filled with lactose solution; and the central and anodic compartments which are filled with an electrolyte solution. Both cathodic and anodic compartments contain a submerged electrode, connected to an electric current generator that promotes the formation of high concentrations of $\mathrm{OH}^{-}$and $\mathrm{H}^{+}$ions in the respective compartments. The communication between the central compartment and the cathodic and anodic ones is performed through anion and cation exchange membranes, respectively. This configuration of the electroactivation reactor ensures high alkalinity in the cathodic compartment where the electroisomerization of lactose takes place. Lactose conversion follows the mechanism of Lobry de Bruyn-van Ekenstein rearrangement and the $\mathrm{pH}$ is considered an important parameter. It is known that a $\mathrm{pH}$ value higher than 9 promotes lactose conversion to lactulose since the hydroxide ions can act as proton acceptors. Using this methodology, and operating at room temperature, it was possible to achieve a $25 \%$ lactulose yield. This yield is similar to that obtained in the chemical synthesis at higher temperatures $\left(70^{\circ} \mathrm{C}\right)$ and in the presence of strong alkaline agents (Aider and Gimenez-Vidal 2012). Furthermore, low concentrations of monosaccharides are detected in the end product $(1.5 \% \mathrm{w} / \mathrm{v}$ galactose and $0.3 \% \mathrm{w} / \mathrm{v}$ fructose) (Aider and Gimenez-Vidal 2012). The optimization of some experimental conditions, such as the electric potential difference, electrolyte concentration in the central compartment, and electroactivation time, led to a small increase in the lactose isomerization (30\%) (Ait Aissa and Aider 2013b). Higher voltages and electrolyte concentrations provide higher lactulose formation. However, under those conditions the temperature inside the reactor can considerably increase and originate lactulose deterioration and/or formation of undesirable by-products. Furthermore, the heating promotes the formation of colored solutions as a result of the Maillard reaction 
A
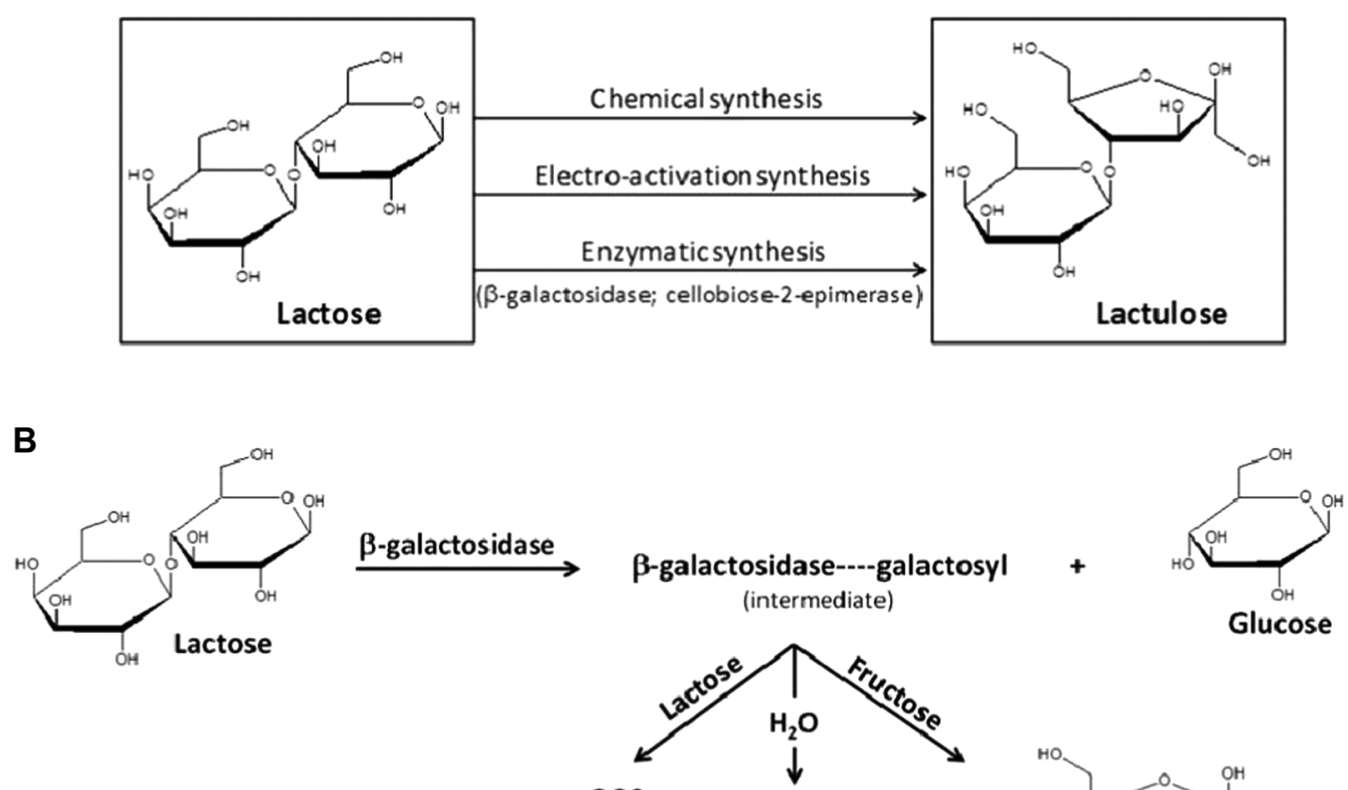

GOS

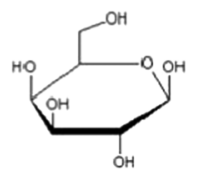

Galactose

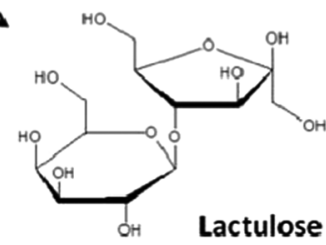

C

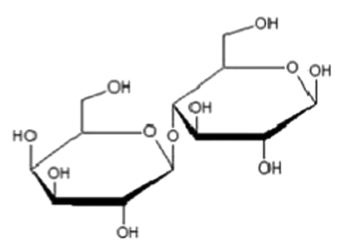

Lactose

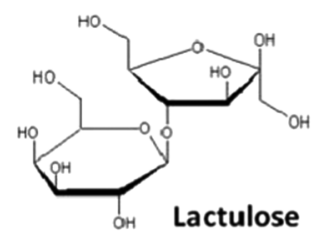

cellobiose-2-epimerase

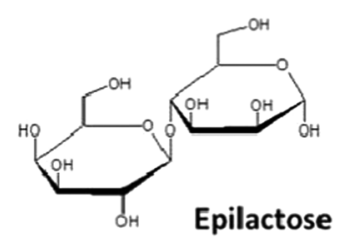

Figure 1-Schematic representation of the different methodologies used to produce lactulose from lactose (A), highlighting the reaction products obtained through enzymatic synthesis using $\beta$-galactosidase (B), and cellobiose-2-epimerase (C).

(Aï Aissa and Aïder 2013b). These detrimental effects can be minimized using a thermostatic bath to ensure refrigerated conditions $\left(<30{ }^{\circ} \mathrm{C}\right)$ during the electroisomerization synthesis. Under these conditions, lactulose is obtained in high purity (around 95\%, excluding the nonisomerized lactose), even when working at 10 or $0{ }^{\circ} \mathrm{C}$. Nevertheless, the lactulose yield is not improved, remaining in the 25\% to 30\% range (Aï Aissa and Aider 2013a, 2014).

\section{Enzymatic synthesis}

Lactulose can also be prepared through an enzymatic route. This alternative approach has received particular attention in the last several decades because it can be a suitable and effective strategy to overcome the disadvantages associated with chemical synthesis.
When enzymes are used as catalysts, reactions are carried out in mild conditions, thus minimizing product degradation. Moreover, enzymes are biodegradable, present higher specificity, and, in general, are well accepted by the food and pharmaceutical industries (Mayer and others 2010; Adrio and Demain 2014). In addition, an enzymatic process can provide a cleaner production of lactulose and, consequently, simplify the purification process (Kim and $\mathrm{Oh}$ 2012).

The enzymatic production of lactulose was 1st described by Vaheri and Kaupinnen (1978). The authors observed the formation of lactulose $(8.6 \mathrm{~g} / \mathrm{L})$ when the enzymatic hydrolysis of lactose by $\beta$-galactosidase occurred in the presence of fructose, at $\mathrm{pH}=7.2$ 
and $37^{\circ} \mathrm{C}$. $\beta$-Galactosidase is known to catalyze the hydrolysis of lactose, yielding glucose and galactose. However, under suitable conditions, this enzyme can also catalyze transgalactosylation reactions. Therefore, the galactosyl moiety from lactose can be transferred to a hydroxyl-containing acceptor (fructose) leading to the synthesis of the disaccharide lactulose $(\beta$-D-galactosyl-(1-4)$\beta$-D-fructose; Figure $1 \mathrm{~B})$ or other possible isomers $(\beta-1,1$ or $\beta-1,6$ bond) depending on the regioselectivity of the enzyme and reaction conditions used. The transfer reaction occurs through a retaining mechanism that involves the formation of a covalent bond between the galactosyl moiety and the enzyme, followed by the transfer of the galactosyl moiety to a nucleophilic acceptor (Gosling and others 2010). Besides fructose, other substances present in the reaction medium, such as water or lactose, can act as acceptors. If water is the acceptor, galactose is obtained, so hydrolysis takes place instead of synthesis (Figure 1B). Nevertheless, when lactose is the acceptor, the synthesis of a different kind of compound occurs, namely the so-called galactooligosaccharide (GOS) (Figure 1B). Both the rate of galactosyl transfer and biochemical nature of the products obtained is dependent on the microbial source of $\beta$-galactosidase (Moulin and Galzy 1984). The formation of additional compounds, such as GOS, can be regarded as a disadvantage if the production of lactulose is envisaged, since it compromises both lactulose yield and purity. However, it is important to bear in mind that GOS compounds have also a prebiotic effect and mixtures of GOS and lactulose may provide a better prebiotic index than lactulose or GOS alone (Guerrero and others 2011).

Besides $\beta$-galactosidase, an additional enzyme was recently described as an efficient biocatalyst for lactulose production, cellobiose-2-epimerase (Kim and Oh 2012; Kim and others 2012 , 2013). In this case, lactulose is obtained from lactose through an isomerization reaction where the glucose moiety of lactose is isomerized to fructose (Figure 1C). The great advantage of this enzyme is the requirement of a single substrate (lactose) in the reaction mixture. Epilactose (4-O- $\beta$-D-galactopyranosyl-D-mannose) is also reported as a product of this enzymatic reaction, as illustrated in Figure 1C.

Despite the potential of the enzymatic synthesis of lactulose, as far as we know, this methodology is not yet commercially used (Szilagyi 2010), maybe due to the low yield associated with these processes. The relatively low transgalactosylation activity of the majority of the enzymes is definitely disappointing. Besides, lactulose can also act as substrate for $\alpha$-galactosidase. Therefore, during the enzymatic reaction the lactulose hydrolysis can prevail over the lactulose synthesis, which obviously contributes to reduce the yields (van Rantwijk and others 1999). To overcome these issues, new and efficient strategies involving promising enzymes from different microbial sources have to be explored. Additionally, protein engineering can make an important contribution in this field. For example, heterologous expression of $\alpha$-galactosidase has been successfully used to obtain high levels of extracellular enzyme (Oliveira and others 2011), making the enzyme recovery and application easier. Using adequate hosts, it is possible to simultaneously improve $\alpha$-galactosidase availability and obtain interesting features like thermostability (Yuan and others 2008) or transgalactosylation activity (Li and others 2009; Nguyen and others 2012; Pawlak-Szukalska and others 2014). On the other hand, the engineering of $\beta$-galactosidase through specific modifications in the amino acid sequence has shown to be able to reduce hydrolytic activity while transglycosylation activity is improved (Feng and others 2005), or to minimize the effect of some inhibitors such as galactose (Hu and others 2010).

Since the original work of Vaheri and Kaupinnen (1978), many other researchers have focused their attention on the enzymatic production of lactulose. Several conditions have been investigated, including the use of free or immobilized enzymes, as well as the application of whole cells as sources of biocatalysts. Table 1 and 2 summarize the conditions that have been reported for the lactulose production through enzyme production and use of commercial enzyme mixtures, respectively.

Integrated process of enzyme and lactulose production. Many microbial sources have been used to produce suitable enzymes for lactulose biosynthesis. These sources include bacteria, yeasts, or molds. Also, different methodologies were tested and optimized toward the maximization of the lactulose formation.

Free enzyme. The reaction conditions and yields that have been reported in the literature for the production of lactulose using free enzymes are summarized in Table 1 . Three enzymes $(\beta-$ glycosidase, $\beta$-galactosidase, and cellobiose-2-epimerase) can be involved in the synthesis of lactulose. Additionally, different $\alpha$ galactosidase microbial sources have also been studied.

Mayer and others (2004) studied the synthesis of lactulose by a hyperthermostable $\beta$-glycosidase from Pyrococcus furiosus which was heterologously produced by Escherichia coli. The enzyme was found to present both $\alpha$-glucosidase (100\%) and $\beta$-galactosidase $(60 \%)$ activity and was obtained after cell disruption without further purification. Some competitive inhibition was observed for $\beta$-glycosidase in the presence of $\mathrm{D}$-glucose. A fructose concentration higher than $90 \mathrm{~g} / \mathrm{L}$ was also found to inhibit the enzymatic activity. The efficiency of free $\beta$-glycosidase and $\beta$-glycosidase immobilized on Eupergit C (see details below for immobilized enzymes) regarding lactulose production was compared, and it was found that the free enzyme provides higher productivity. The results obtained were also compared with those achieved when using a commercial $\beta$-galactosidase from Aspergillus oryzae, free enzyme), thus suggesting that the $\beta$-glycosidase provides a higher lactulose yield. A later study using a $\beta$-glycosidase from $P$. furiosus for the continuous lactulose production in an enzyme membrane reactor showed that, under these conditions, the maximal lactulose concentration decreased, although the productivity was improved (Mayer and others 2010). However, it was pointed out that a high reaction temperature (the optimal temperature for $\beta$-glycosidase is $75^{\circ} \mathrm{C}$ ) and a high substrate concentration (34 g/L lactose; $270 \mathrm{~g} / \mathrm{L}$ fructose) can bring about some browning of the reaction mixture due to the occurrence of nonenzymatic reactions (Mayer and others 2004, 2010). To prevent this issue, Tang and others (2011) proposed the use a $\beta$-galactosidase from Arthrobacter sp. (optimal temperature $=20^{\circ} \mathrm{C}$ ) for the synthesis of lactulose. The enzyme was obtained after cell disruption and was purified by ammonium sulfate precipitation and hydrophobic chromatography. Lactulose production was confirmed by high-performance liquid chromatography (HPLC) analysis; however, neither the yield nor the productivity obtained were reported. Pawlak-Szukalska and others (2014) also reported a cold-active $\beta$-galactosidase from Arthrobacter sp. expressed in E. coli. This enzyme exhibited $42 \%$ of its maximum hydrolytic activity at $10{ }^{\circ} \mathrm{C}$ and showed transglycosylation activity from 10 to $30^{\circ} \mathrm{C}$. Lactulose synthesis was confirmed by thin-layer chromatography, with the best result obtained after $8 \mathrm{~h}$ of reaction at $30^{\circ} \mathrm{C}$. However, only qualitative analysis of lactulose was carried out and no detailed information about the productivity and yield was presented. 

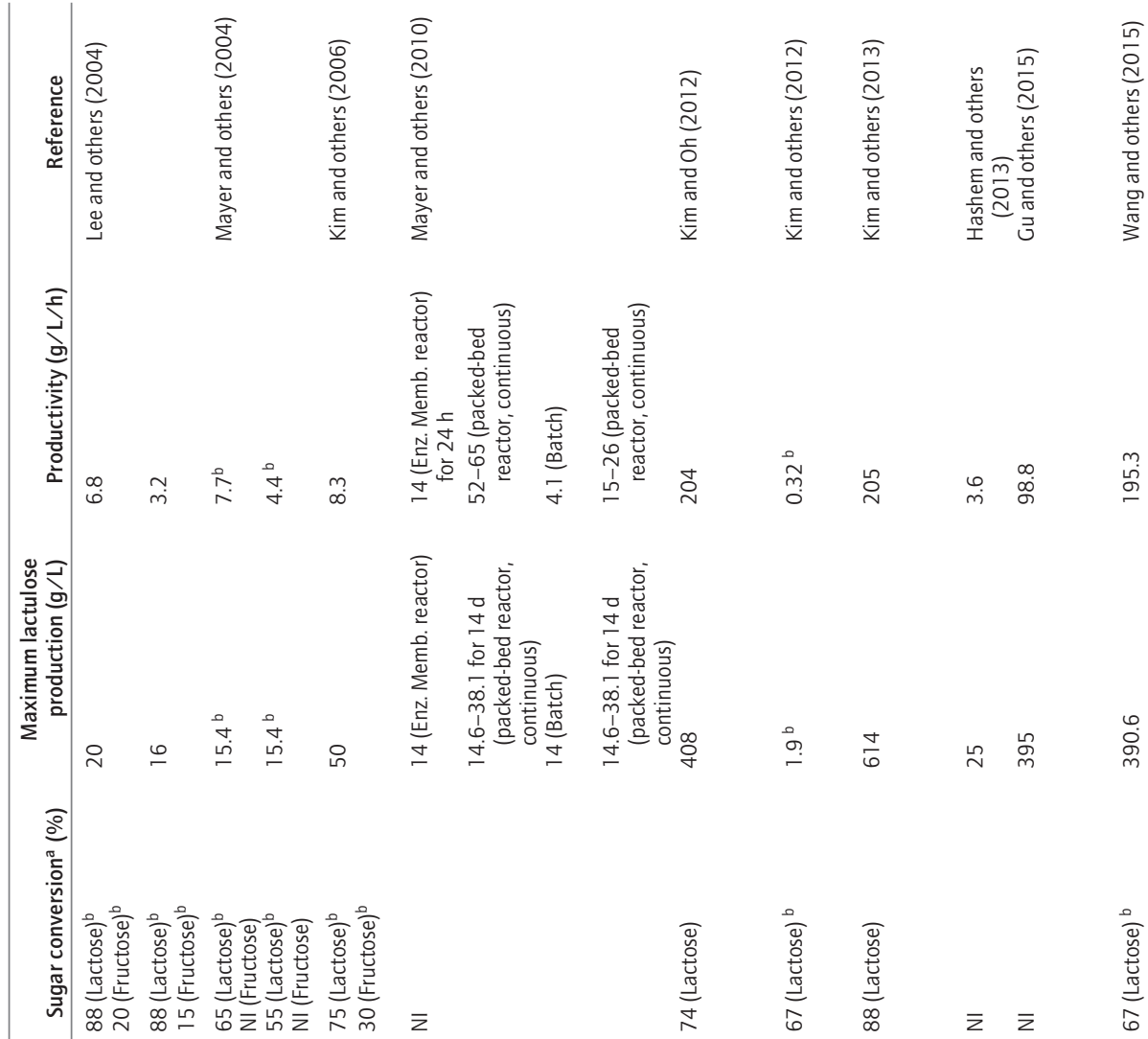

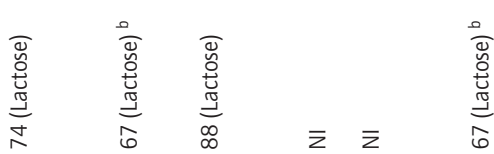
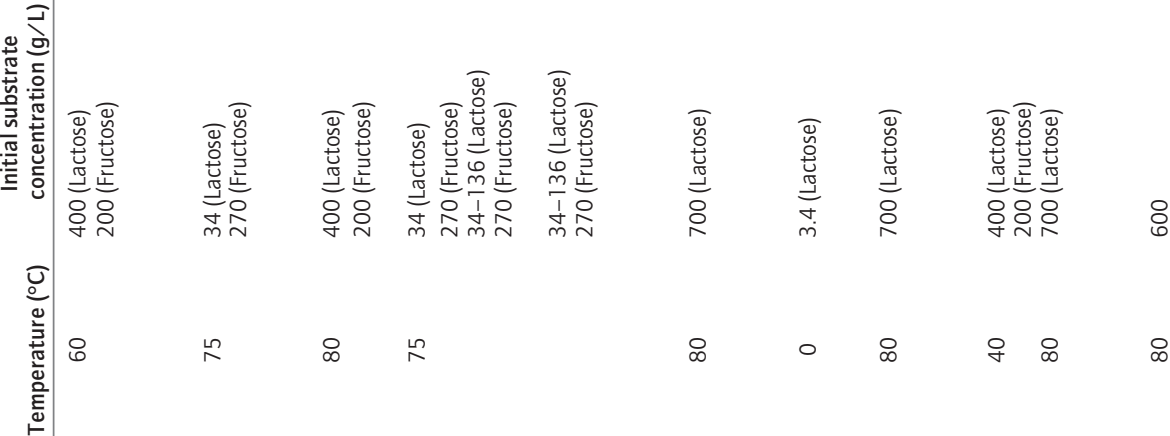

I용 웃

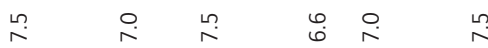
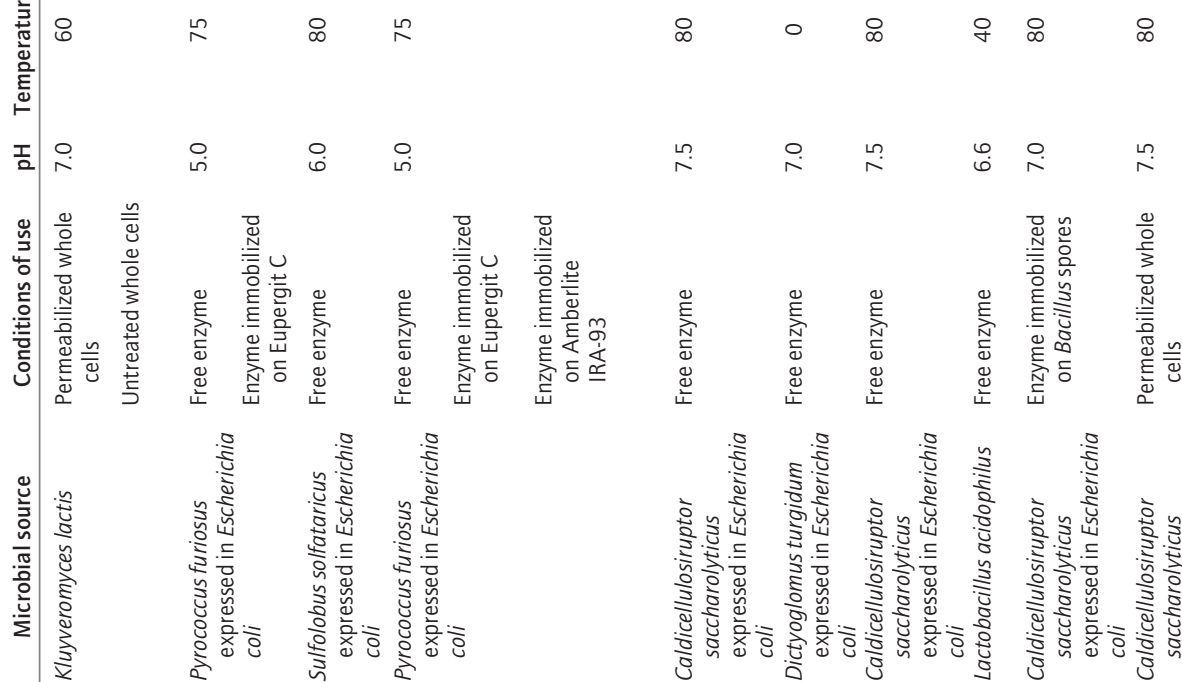

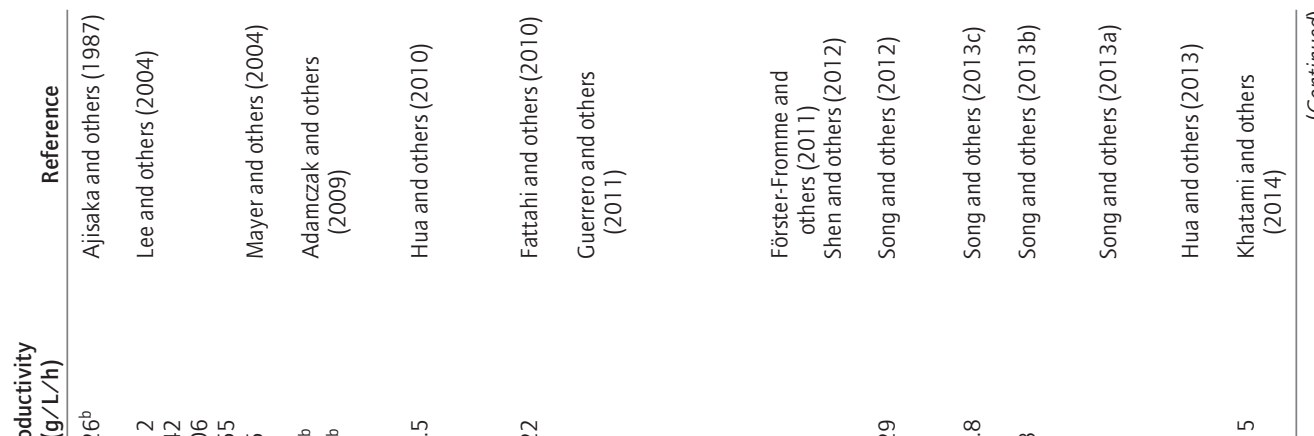

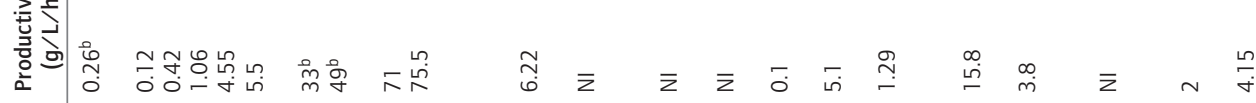

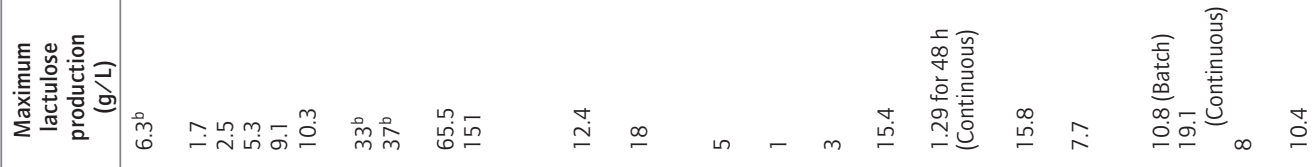

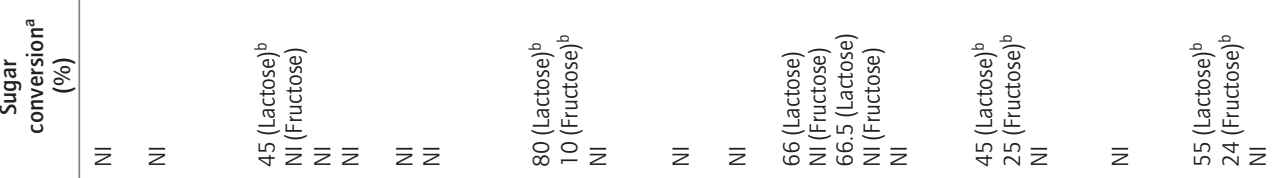

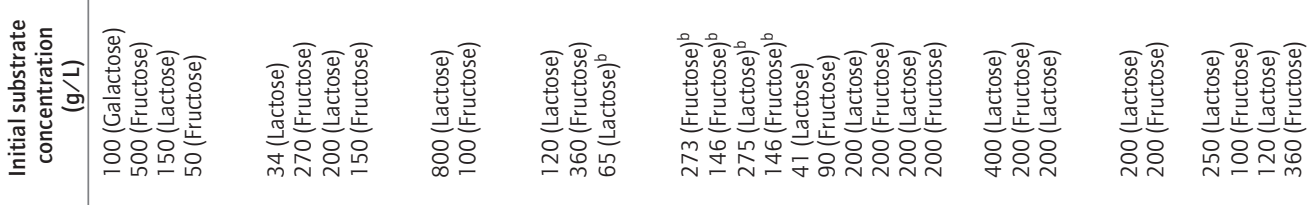

(0

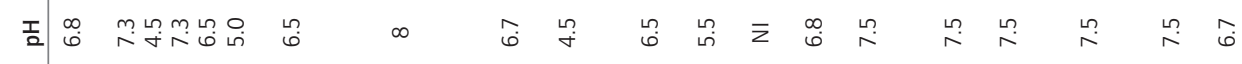

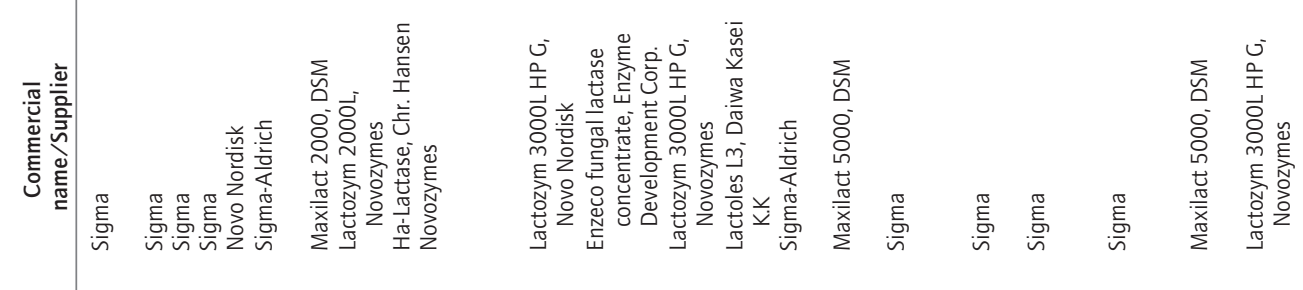
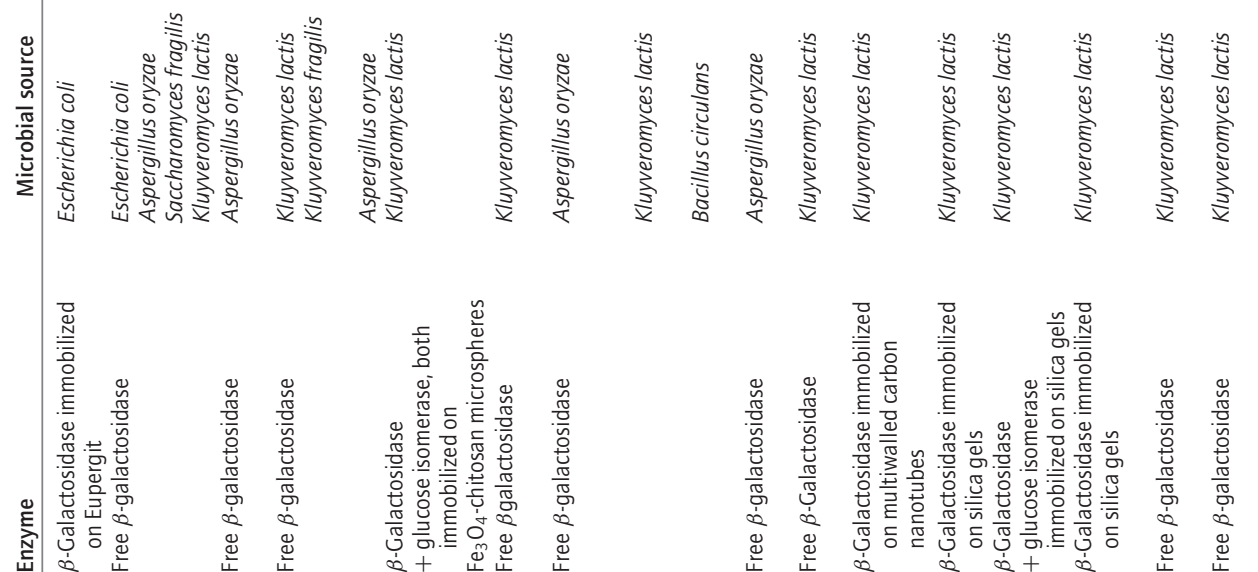


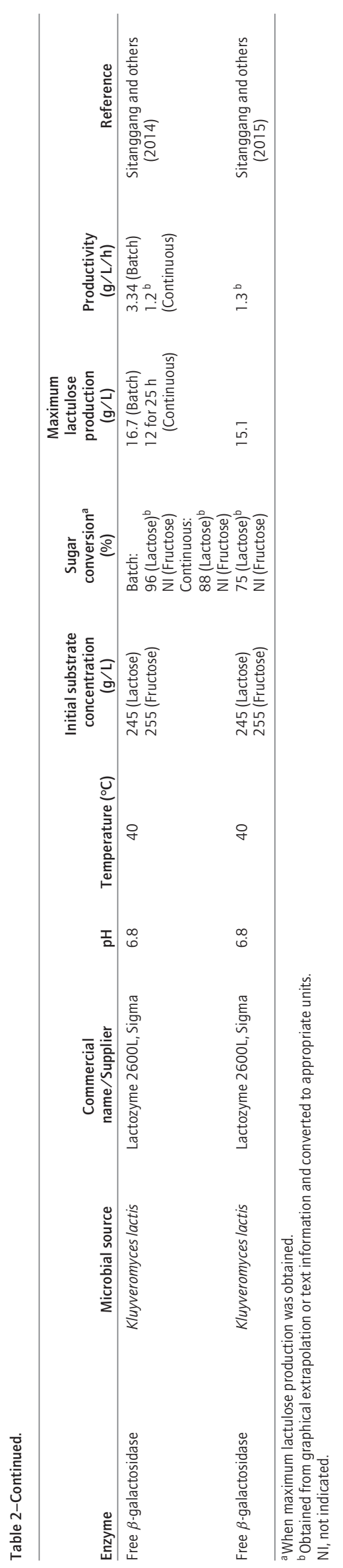

Kim and others (2006) reported the lactulose production by a recombinant $\beta$-galactosidase from the hyperthermophilic bacterium Sulfolobus solfataricus. E. coli cells were cultured in the presence of isopropyl- $\beta$-D-thiogalactopyranoside (IPTG) and after disruption and centrifugation, the obtained supernatant was used for lactulose production without further purification. The optimal conditions found for lactulose production were lactose $(400 \mathrm{~g} / \mathrm{L})$, fructose $(200 \mathrm{~g} / \mathrm{L}), \mathrm{pH}=6.0$, and $80{ }^{\circ} \mathrm{C}$. This high temperature indicates that $\beta$-galactosidase from $S$. solfataricus is a very thermostable enzyme. The lactulose concentration achieved $(50 \mathrm{~g} / \mathrm{L})$ was considerably high if compared with the values generally reported in the literature (Table 1).

Lactulose synthesis by a nonpurified $\beta$-galactosidase obtained from Lactobacillus acidophilus was proposed by Hashem and others (2013). Under the optimal conditions for the transgalactosylation reaction, a maximum lactulose concentration of $25 \mathrm{~g} / \mathrm{L}$ was obtained. Lower lactulose concentration ( 5 to $6 \mathrm{~g} / \mathrm{L}$ ) was obtained using $\beta$-galactosidase from Klebsiella pneumonia, expressed in E. coli (Wang and others 2014). In this case, also 1-lactulose, an isomer of lactulose, was detected.

A new thermostable enzyme was recently proposed as biocatalyst in lactulose production, namely the cellobiose-2-epimerase (Kim and Oh 2012; Kim and others 2012, 2013). This enzyme catalyzes the isomerization reaction that converts the glucose moiety of lactose to fructose (Figure 1C). Therefore, only lactose is required as the substrate. However, besides lactulose, a minor product named epilactose is also formed. Originally, cellobiose2-epimerase from the thermophilic organism Caldicellulosiruptor saccharolyticus was expressed in E. coli and the cells were cultured in appropriate medium using IPTG to induce the enzyme expression. After cell disruption, the enzyme was purified through His-Trap affinity chromatography to obtain the enzymatic fraction required for the lactulose production. In the 1st work, the effect of $\mathrm{pH}$ and temperature in lactulose production was investigated and it was found that the optimal conditions were $\mathrm{pH}=7.5$ and $T=80{ }^{\circ} \mathrm{C}$ (Kim and $\mathrm{Oh} 2012$ ). This high temperature (probably a consequence of the microorganism origin) can provide a higher reaction velocity and solubility of the substrate (lactose). Regarding the effect of substrate concentration in product formation, it was observed that both lactulose and epilactose concentration increased linearly with lactose concentration in the range 50 to $700 \mathrm{~g} / \mathrm{L}$. Therefore, the conversion yields of lactulose and epilactose remained almost constant at approximately $60 \%$ and $15 \%$, respectively. Under optimal conditions, $408 \mathrm{~g} / \mathrm{L}$ of lactulose and $107 \mathrm{~g} / \mathrm{L}$ of epilactose were obtained, which is a noteworthy value in the enzymatic synthesis of lactulose (Table 1). However, this value was even higher when borate $(120 \mathrm{~g} / \mathrm{L})$ was added to the reaction mixture (Kim and others 2013). In this case, $614 \mathrm{~g} / \mathrm{L}$ of lactulose and $12 \mathrm{~g} / \mathrm{L}$ of epilactose were obtained after $3 \mathrm{~h}$ of reaction, thus representing a conversion yield of $88 \%(\mathrm{w} / \mathrm{w})$, which is comparable with that obtained by chemical synthesis. Furthermore, the concentration of the by-product, epilactose, was less than $2 \%$ of the final reaction product. This represents the best lactulose production values ever described in the literature for enzymatic synthesis (Table 1 and 2). The addition of borate leads to the formation of borate-lactulose complexes, which contributed to the constant removal of lactulose and induced its continuous formation. The disadvantage of this methodology arises from the need to remove the borate, which is ensured only in $99 \%$ using Amberlite IRA-743 and Dowex X50X8 resins. Therefore, further research for the complete elimination of borate is required. Another work from the same research group demonstrated that 
cellobiose-2-epimerase from Dictyoglomus turgidum expressed in E. coli has also the ability to convert lactose into lactulose (Kim and others 2012). The reaction conditions used were $70^{\circ} \mathrm{C}, \mathrm{pH} 7.0$, and a reduced concentration of lactose $(10 \mathrm{mM})$. Lactose conversion under these conditions was around $67 \%$ and maximal lactulose concentration $(1.9 \mathrm{~g} / \mathrm{L})$ was obtained after $6 \mathrm{~h}$.

Immobilized enzyme. The reaction conditions and yields reported in the literature for lactulose production using immobilized enzymes are also summarized in Table 1. Enzyme immobilization can offer several advantages in the enzymatic synthesis, namely the easy and fast separation of the biocatalyst from the reaction mixture without additional denaturation and/or purification steps. However, the immobilization can considerably affect the enzyme properties, namely the optimal temperature and $\mathrm{pH}$, or the kinetic and stability parameters. For this reason, special attention should be paid to the immobilization technique or support used. Mass transfer limitations could be a major drawback for lactulose production by immobilized enzymes.

As previously mentioned, Mayer and others (2004) carried out a preliminary study where a recombinant $\beta$-glycosidase from P. furiosus was immobilized on Eupergit $\mathrm{C}$ and its ability to produce lactulose was evaluated. The maximal lactulose concentration was similar to that obtained for experiments conducted with the free enzyme (around $15 \mathrm{~g} / \mathrm{L}$ ), but the productivity was found to be 1.7-fold lower. In both cases, using free or immobilized enzyme, lactulose represented more than $95 \%$ of the products formed by transgalactosylation. These preliminary results led to further studies involving the continuous lactulose production in an enzyme membrane reactor (free enzyme) and packed-bed reactor using immobilized $\beta$-glycosidase from P. furiosus (Mayer and others 2010). Besides Eupergit C, other support was studied for the enzyme immobilization, namely the anion-exchange resin Amberlite IRA93. This new support proved to be more efficient in the lactulose production, providing a higher productivity than that obtained for $\beta$-glycosidase immobilized on Eupergit C. In both cases of immobilization, the enzyme showed high operational stability in the packed-bed reactors, operating for at least $14 \mathrm{~d}$, without loss of activity. Furthermore, the results obtained in immobilized conditions were higher than those found for free enzyme in the enzyme membrane reactor (Mayer and others 2010).

Recently, lactulose production using recombinant cellobiose 2-epimerase from C. saccharolyticus immobilized in Bacillus subtilis spores was reported (Gu and others 2015). Bacillus spores have been described as a robust, inexpensive, and recyclable support which provides food-grade safety since Bacillus bacteria have been used as probiotics in human food and animal feed (Sirec and others 2012). Therefore, their application in enzyme immobilization was proposed as a simple and practical alternative to the conventional organic and inorganic supports. The immobilization of cellobiose 2-epimerase in the nonrecombinant B. subtilis spores occurred through adsorption and the enzyme retained approximately $70 \%$ of its initial activity after 8 cycles of reaction. Maximum lactulose production $(395 \mathrm{~g} / \mathrm{L})$ was obtained after $4 \mathrm{~h}$ of reaction and using $700 \mathrm{~g} / \mathrm{L}$ of lactose. The value achieved for lactulose production was similar to that reported by $\mathrm{Kim}$ and $\mathrm{Oh}$ (2012) for the free enzyme (Table 1). Nevertheless, it is important to consider that the immobilization provided an improvement in the thermal stability of the enzyme and also allowed its reuse.

Whole cells. The use of biocatalysts in the form of whole cells can offer some advantages over purified enzymes, as, for example, the reduction of costs and number of steps involved in the enzy- matic synthesis. Furthermore, the enzyme is acting in its natural environment under its optimal conditions and is protected from destabilizing or degrading effects (Schüürmann and others 2014). In addition, the use of whole cells can represent an economical and easy-to-handle process for lactulose production (Wang and others 2015). However, the use of whole cell biocatalysts with intracellular enzymes requires the previous permeabilization of the cell membrane to make possible the interaction between the enzyme and the substrate and also the release of the product (Schüurmann and others 2014). The work by Lee and others (2004) was probably the 1st to report the use of whole cells for lactulose production. These authors treated whole cells of Kluyveromyces lactis (source of $\beta$-galactosidase) with ethanol (50\% v/v) to reduce the permeability barrier. Lactulose production, under optimal conditions, was investigated for both permeabilized and untreated whole cells. It was found that permeabilized cells provided a lactulose concentration 1.3-fold higher than that obtained for untreated cells. Furthermore, the lactulose productivity for permeabilized cells was increased 2.1-fold when compared with untreated cells. This improvement was probably due to a faster mass transfer of substrates and products, a better contact with the substrate, and an easier product release achieved through cell permeability. In the time-course reaction, lactulose production reached a maximum concentration at $3 \mathrm{~h}$, which decreased afterwards. This fact can be a consequence of some product degradation. Besides lactulose, other oligosaccharides such as GOS compounds were also detected by HPLC.

In a different work, Wang and others (2015) reported the use of recombinant $E$. coli cells containing cellobiose 2-epimerase from C. saccharolyticus for lactulose production using lactose as a single substrate. Once more, ethanol was the agent chosen to treat the cells and reduce the permeability barrier. Hence, the effectiveness of ethanol as a permeabilizing agent was evaluated and the optimal concentration and contact time was defined as $40 \%$ (v/v) ethanol for $30 \mathrm{~min}$. The optimal $\mathrm{pH}$, temperature, substrate concentration, and volumetric activity of the biocatalyst were also investigated and reported as $7.5,80^{\circ} \mathrm{C}, 600 \mathrm{~g} / \mathrm{L}$ of lactose, and $12.5 \mathrm{U} / \mathrm{L}$, respectively. Under these conditions, maximal lactulose concentration of $318 \mathrm{~g} / \mathrm{L}$ was achieved after $2 \mathrm{~h}$. However, when borate was added to the reaction mixture in a molar ratio of $1: 1$ borate-tolactose, the lactulose yield increased $13 \%$ due to the formation of borate-lactulose complexes, as explained above for free cellobiose 2-epimerase (free enzyme division/subsection). The buffer composition also showed an important effect in the amount of lactulose and epilactose obtained at the end of the synthesis. Using sodium phosphate buffer $(50 \mathrm{mM}, \mathrm{pH} 7.5)$ the highest lactulose concentration $(390.6 \mathrm{~g} / \mathrm{L})$ and the lowest epilactose concentration $(11.7 \mathrm{~g} / \mathrm{L})$ were obtained.

Lactulose prebiotic production using commercial enzyme mixtures. There are several commercial enzyme mixtures of $\alpha$ galactosidase that have been studied for industrial lactulose production. Among them, Maxilact from DSM and Lactozym from Novozymes are probably the most common. The enzyme mixtures are obtained from different microbial sources and have been used both in free and immobilized conditions providing some interesting results, as discussed below.

Free enzyme. The reaction conditions and yields reported in the literature for lactulose production using commercial free enzymes are collected in Table 2 . $\beta$-Galactosidase was the only commercial enzyme used as free biocatalyst for the lactulose synthesis. However, different microbial sources of this enzyme have been reported. 
Lee and others (2004) were probably the 1st to compare the efficiency of several commercial $\alpha$-galactosidases from different microbial sources for the production of lactulose. $\beta$-Galactosidase from E. coli (Sigma, St. Louis, Mo., U.S.A.), A. oryzae (Sigma, St. Louis, Mo., U.S.A.), Saccharomyces fragilis (Sigma, St. Louis, Mo., U.S.A.), and Kluyveromyces lactis (Novo Nordisk, Seoul, South Korea) were tested under their respective optimal conditions. The highest lactulose productivity $(4.55 \mathrm{~g} / \mathrm{L} / \mathrm{h})$ was obtained for the $\alpha$-galactosidase from $K$. lactis. A slightly higher productivity $(5.5 \mathrm{~g} / \mathrm{L} / \mathrm{h})$ was obtained by Mayer and others (2004) using a $\beta$-galactosidase from A. oryzae (Sigma-Aldrich, Seelze, Germany) but different $\mathrm{pH}$, temperature, and substrate concentration.

More recently, Adamczak and others (2009) compared the efficiencies of 3 commercial preparations of $\beta$-galactosidase in lactulose synthesis, namely Maxilact 2000 from K. lactis (DSM, Warsaw, Poland), Lactozym 2000L from K. fragilis (Novozymes, Poland), and Ha-Lactase from A. oryzae (Chr. Hansen, Croatia). The effects of different fructose concentrations $(50,100$, and $150 \mathrm{~g} / \mathrm{L})$ were also evaluated. The lactulose yield varied according to the source of $\beta$-galactosidase and the highest value $(65.5 \mathrm{~g} / \mathrm{L})$ was obtained when Ha-lactase and $150 \mathrm{~g} / \mathrm{L}$ fructose were used. Indeed, this is one of the highest values obtained for the lactulose synthesis using commercial enzymes (Table 2).

Fattahi and others (2010) also used a $\beta$-galactosidase from $K$. lactis (Lactozym 3000L HP G, Novo Nordisk, Iran) to obtain lactulose. In this case, the effects of some parameters such as the reaction time, fructose concentration, temperature, and enzyme amount were evaluated. Similarly, maximal lactulose concentration was obtained for the highest fructose concentration used $(30 \% \mathrm{w} / \mathrm{w})$, thus suggesting that higher fructose concentrations are preferable for the synthesis of lactulose. The increase of temperature did not significantly affect the maximum lactulose concentration, but reduced the time necessary to reach that concentration. On the other hand, the reduction of enzyme amount used led to an increase in the time needed to obtain a maximal lactulose concentration.

Commercial $\beta$-galactosidase preparations from Bacillus circulans (Lactoles L3 from Daiwa Kasei K.K., Amano, Japan), K. lactis (Lactozym 3000L HP G from Novo Nordisk, Brasil), and A. oryzae (Enzeco fungal lactase concentrate from Enzyme Development Corp. [EDC], New York, NY, U.S.A.) were studied by Guerrero and others (2011) as catalysts for the production of lactulose. The composition of the mixture (lactulose and GOS) obtained at the end of the reaction was strongly dependent on the biocatalyst used. $\beta$-Galactosidase from $A$. oryzae produced similar concentrations of both lactulose and GOS, while the $\beta$-galactosidase from $K$. lactis and $B$. circulans produced essentially GOS. After selecting $A$. oryzae as the most efficient enzyme source, the impact of some operational variables $(\mathrm{pH}$, temperature, initial substrate concentration, enzyme-to-substrate ratio, and lactose-to-fructose initial molar ratio) was also investigated by the authors. Among these variables, the initial molar ratio of lactose-to-fructose proved to be the most significant for the final product composition. It was found that when using an initial molar ratio of 1:8, the lactulose synthesis prevailed over the GOS synthesis. Another important fact observed was the possibility to control the product composition (lactulose and GOS proportions) by manipulating the initial molar ratio of lactose-to-fructose. To better understand the effect of the reaction conditions on the synthesis of both GOS and lactulose, as well as to improve the catalytic potential of $\beta$-galactosidase from A. oryzae (Enzeco fungal lactase concentrate, EDC, New York, NY, U.S.A.), another study was carried out by the same research group (Vera and others 2011). The study revealed that galactose can induce an inhibitory effect, which is significantly stronger for the transgalactosylation activity than for the hydrolysis activity. Additionally, glucose concentrations lower than $70 \mathrm{~g} / \mathrm{L}$ can activate the transgalactosylation activity. However, higher glucose concentrations inhibit such activity. All these aspects suggest the need to develop new strategies to remove the products of lactose hydrolysis from the reaction medium to maximize the lactulose production (Vera and others 2011).

The $\alpha$ synthesis of lactulose from lactose present in a milk serum drink was also evaluated using $\beta$-galactosidase from $A$. oryzae (Sigma-Aldrich, München, Germany) in a pilot-plant-scale process (maximum batch volume of $170 \mathrm{~L}$ ) (Förster-Fromme and others 2011). The enzymatic reaction took place in the presence of fructose, at $6{ }^{\circ} \mathrm{C}$. Maximum lactulose concentration was obtained at $30 \mathrm{~h}$; however, the enzymatic reaction was only stopped after 48 $\mathrm{h}$ by heating the mixture at $127^{\circ} \mathrm{C}$ for $10 \mathrm{~s}$. Besides lactulose, it was also detected the formation of 1-lactulose ( $\beta$-D-galactopyranosyl(1-1)- $\beta$-D-fructose), which is present in a higher concentration than lactulose. The obtained milk serum drink was composed of lactose $(6.9 \mathrm{~g} / \mathrm{L})$, fructose $(85 \mathrm{~g} / \mathrm{L})$, a mixture of galactose and glucose $(75 \mathrm{~g} / \mathrm{L})$, lactulose $(2.5 \mathrm{~g} / \mathrm{L})$, and 1-lactulose $(3.2 \mathrm{~g} / \mathrm{L})$. Moreover, this drink was further evaluated in a pilot study in which the participants consumed it for $14 \mathrm{~d}$. Two placebo milk drinks were also included in the test, namely a milk drink with a lactulose additive (obtained by chemical synthesis) and a milk serum drink without lactulose. The results obtained indicated that the milk drink with enzymatically synthesized lactulose has a slightly higher prebiotic index than the product containing the chemically synthesized lactulose. Furthermore, the bifidogenic effect of 1 lactulose was shown and this compound was considered to possess prebiotic properties.

Lactulose and 1-lactulose were also reported by Shen and others (2012) and Hua and others (2013) as the major products of the enzymatic synthesis when using $\beta$-galactosidase from $K$. lactis (Maxilact 5000, DSM, Beijing, China). In both cases, the concentration of 1-lactulose was approximately 3 -fold higher than the concentration of lactulose, thus suggesting the preference of this commercial enzyme for establishing $\beta-1,1$ bonds. Furthermore, Hua and others (2013) showed that higher fructose concentrations promote lactulose production and retard lactose hydrolysis. This effect on lactose hydrolysis was attributed to the ability of fructose to strongly attract water molecules in the neighborhood, which minimize the probability of the galactosyl group to react with water. The priority of fructose over lactose as a galactosyl acceptor has also been reported, since the synthesis of GOS was not observed in the presence of fructose. Lorenzen and others (2013) also detected the formation of another isomer besides lactulose, the allolactose ( $\beta$-D-galactopyranosyl-(1-6)- $\beta$-D-glucose). These products were obtained from the treatment of ultrafiltrated-skim milk with a bienzymatic system composed by $\beta$-galactosidase from K. lactis (Lactozym 3000L HP-G, Novozymes, Bagsvaerd, Denmark) and glucose isomerase. However, the concentrations of lactulose and allolactose produced were not reported by the authors.

Recently, the use of nonconventional media for lactulose production by the commercial $\beta$-galactosidase from $K$. lactis (Lactozym 3000L HP G, Novozymes, Bagsvaerd, Denmark) was evaluated by Khatami and others (2014). First, the optimum concentrations of lactose and fructose were selected in an aqueous medium. For high lactose concentrations $(15 \%$ to $20 \% \mathrm{w} / \mathrm{w})$, it was observed the formation of oligosaccharides 
other than lactulose, as well as restrictions on the solubility of other compounds involved in the enzymatic synthesis. On the other hand, an increase of fructose concentration promoted lactulose production due to the reduction in the water activity, and a maximum was obtained with $30 \%(\mathrm{w} / \mathrm{w})$ fructose. Above this value, lactulose production decreased, probably due to an inhibitory effect on the $\beta$-galactosidase activity. Acetone and triethyl phosphate were the organic solvents used to obtain the 1-phase aqueous-organic medium for the enzymatic synthesis. For acetone, a decrease was observed in the lactulose production when compared with conventional medium. This negative effect can be a consequence of the reduction of $\beta$-galactosidase activity, since no hydrolytic activity was found at an acetone concentration above $30 \%(\mathrm{w} / \mathrm{w})$. On the contrary, a 20\% increase of the lactulose production was found when $30 \%(\mathrm{w} / \mathrm{w})$ of triethyl phosphate was used.

Lactulose synthesis using an enzymatic membrane reactor under batch and continuous operation, and $\beta$-galactosidase from $K$. lactis (Lactozyme, Sigma, Germany) as catalyst was described by Sitanggang and others (2014). The effect of total sugar concentration, enzyme concentration, and molar ratio of lactose-to-fructose was 1 st investigated in a batch process. After establishing some parameters, namely sugar concentration of $500 \mathrm{~g} / \mathrm{L}$, enzyme concentration of $300 \mathrm{U}$, and a molar ratio of lactose to fructose of 0.5 , the production of lactulose was studied under continuous conditions. When comparing the batch process with the continuous one, a decrease in the maximum lactulose production $(16.7 \mathrm{~g} / \mathrm{L}$ in the batch) to approximately $12 \mathrm{~g} / \mathrm{L}$ in the continuous process was observed. However, the continuous process provided a constant lactulose production for $25 \mathrm{~h}$, suggesting that secondary hydrolysis of lactulose, one of the main drawbacks of the enzymatic synthesis, is practically absent under those operational conditions. Furthermore, shorter hydraulic retention time (HRT) $(5 \mathrm{~h})$ provided higher specific productivity than longer HRT $(7 \mathrm{~h})$. This fact was attributed to the higher amount of permeate produced over time when using a shorter HRT. Nevertheless, the product concentration under this condition is generally lower. To evaluate in detail the effect of HRT on lactulose production, Sitanggang and others (2015) used the same enzymatic membrane reactor and tested HRTs from 3 up to $9 \mathrm{~h}$. This study revealed that shorter HRTs ( $3 \mathrm{~h}$ and $5 \mathrm{~h}$ ) provided higher specific productivity, but longer HRTs ( $7 \mathrm{~h}$ and $9 \mathrm{~h}$ ) led to higher lactulose concentrations. Shorter HRTs were associated with a reduced time for lactose hydrolysis and, consequently, a lower amount of galactosyl moieties was available for lactulose production by transgalactosylation. Additionally, shorter HRT also represented a shorter time for the occurrence of the necessary transgalactosylation reactions. For those reasons, the authors evaluated the long-term continuous synthesis of lactulose considering lactulose concentration as the most important parameter and using an HRT of $9 \mathrm{~h}$ and the optimal conditions previously defined (Sitanggang and others 2014). Under these conditions, the maximal lactulose concentration obtained was approximately $15 \mathrm{~g} / \mathrm{L}$ after $11.5 \mathrm{~h}$ of operation. Besides, a nearly constant lactulose concentration of around $14 \mathrm{~g} / \mathrm{L}$ was obtained in the period 23 to $32 \mathrm{~h}$. After that, lactulose concentration gradually decreased to approximately $10 \mathrm{~g} / \mathrm{L}$ at the end of the process $(168 \mathrm{~h})$. Both the reduction of the enzyme activity (around 31\% after $168 \mathrm{~h}$ ) and the increase of transmembrane pressure were considered important factors in the long-term continuous production of lactulose since they had a negative impact. The tendency of the enzyme to adsorb onto the polyethersulfone membrane of the reactor led to a simultaneous increase in the transmembrane pressure and a decrease on the hydrolytic activity of the enzyme, which obviously had a negative effect on the lactulose production and can justify the gradual reduction observed from 32 to $168 \mathrm{~h}$.

Immobilized enzyme. Eupergit was used by Ajisaka and others (1987) to immobilize $\beta$-galactosidase from E. coli (Sigma) and to evaluate the ability of the enzyme to synthesize lactulose and all lactulose by reversed hydrolysis. These authors proposed a system, composed of a column with the immobilized enzyme where the synthesis took place, which is connected to a column filled with activated carbon where the separation of the saccharides occurred. A buffer solution $(\mathrm{pH}=6.8)$ containing $100 \mathrm{~g} / \mathrm{L}$ of galactose and $500 \mathrm{~g} / \mathrm{L}$ of fructose was circulated in the system for $24 \mathrm{~h}$ leading to a lactulose production of $6.3 \mathrm{~g} / \mathrm{L}$.

Later, Hua and others (2010) proposed the synthesis of lactulose via a dual-enzymatic method, using $\beta$-galactosidase from $K$. lactis (Novozymes, China) and glucose isomerase, in an organic-aqueous 2-phase medium. In this case, both enzymes were immobilized in magnetic microspheres composed by $\mathrm{Fe}_{3} \mathrm{O}_{4}$ and chitosan. The advantage of using glucose isomerase makes it possible to convert the glucose originating from the lactose hydrolysis into fructose, thus increasing the concentration of the substrate in the medium throughout the reaction time. Another innovation of this work was the replacement of the traditional aqueous medium by an organic one. Three organic solvents (cyclohexane, ethyl acetate, and n-butanol) were evaluated by preparing mixtures of organic solvent:water (95:5); and for all of them lactulose production was higher than in deionized water. Organic-aqueous medium is responsible for lowering the water activity which can improve the transgalactosylation activity of $\beta$-galactosidase. Under the optimal conditions (cyclohexane:buffer $\mathrm{pH}=8(95: 5), 30{ }^{\circ} \mathrm{C}, 800 \mathrm{~g} / \mathrm{L}$ initial lactose feed, and $100 \mathrm{~g} / \mathrm{L}$ initial fructose feed), the maximum lactulose concentration was $151 \mathrm{~g} / \mathrm{L}$, which is a remarkable value considering the yields generally obtained by enzymatic synthesis (Table 2).

The continuous production of lactulose using a multiwalled reactor of carbon nanotubes containing immobilized $\beta$-galactosidase from K. lactis (Sigma, St. Louis, Mo., U.S.A.) was reported by Song and others (2012). Before immobilization, the enzyme was pretreated with lactose to improve its activity, as previously described by the same authors (Song and others 2010). Lactose can have a positive steric effect at the active site of the enzyme ensuring that only the enzymatic regions far from the active site will react with the support. When operating with this reactor, lactulose was continuously synthesized at a concentration of $1.29 \mathrm{~g} / \mathrm{L}$ during $48 \mathrm{~h}$. The same research group also immobilized $\beta$-galactosidase from K. lactis (Sigma, St. Louis, Mo., U.S.A.) on silica gels and optimized the reaction conditions for lactulose synthesis (Song and others 2013c). Reaction parameters such as substrate concentration, $\mathrm{pH}$ and ion strength of the buffer, temperature, and enzyme concentration were studied. Regarding the substrate concentration, it was found that $400 \mathrm{~g} / \mathrm{L}$ lactose and $200 \mathrm{~g} / \mathrm{L}$ fructose (molar ratio of 1:1) were the optimal conditions. The best enzyme concentration was established at $12 \mathrm{U} / \mathrm{mL}$ and temperature at $47^{\circ} \mathrm{C}$. Concerning the buffer composition, it was shown that sodium phosphate buffer $\mathrm{pH}=7.5(50 \mathrm{mM})$ was the most effective for the synthesis of lactulose. Under optimal conditions, the lactulose productivity was $15.8 \mathrm{~g} / \mathrm{L}$ per h. Furthermore, the immobilized enzyme could retain $60.5 \%$ of its original catalytic activity after 10 cycles of reutilization. After optimizing the reaction conditions, the immobilized $\beta$-galactosidase from $K$. lactis (Sigma, St. Louis, Mo., U.S.A.) together with an immobilized 
glucose isomerase from Streptomyces rubiginosus (Hampton Research, San Diego, CA, U.S.A.) were used in another study carried out by Song and others (2013b). In this case, cheese whey was used as the lactose source and no fructose was supplied to the reaction mixture. Besides the conventional reaction parameters such as $\mathrm{pH}$, temperature, or substrate concentration, the enzyme ratio proved to have an important effect in the synthesis of lactulose. Indeed, it was found that a relatively high concentration of glucose isomerase is necessary to ensure a fructose concentration adequate for the transgalactosylation reaction. The 1:5 ratio of $\beta$-galactosidaseto-glucose isomerase led to the highest lactulose concentration $(7.54 \mathrm{~g} / \mathrm{L})$. The immobilized enzymes retained $57.1 \%$ of their original catalytic activity after 7 cycles of reutilization. Continuous lactulose production in a packed-bed reactor using $\beta$-galactosidase immobilized on silica gel, and cheese whey as the lactose source was also investigated by the same authors (Song and others 2013a). However, in this case, fructose $(200 \mathrm{~g} / \mathrm{L})$ was added to the reaction mixture, corresponding to a 1:2 molar ratio of lactose-to-fructose. Continuous lactulose synthesis was affected by the flow rate used in the process, with the highest lactulose concentration $(19.1 \mathrm{~g} / \mathrm{L})$ obtained for $0.5 \mathrm{~mL} / \mathrm{min}$. This concentration is superior to that obtained in the batch process $(10.8 \mathrm{~g} / \mathrm{L})$, which could be due to the decrease of some inhibitors (namely galactose and glucose) during the enzymatic reaction.

In a different study, $\beta$-galactosidase from $A$. oryzae (Enzeco fungal lactase concentrate from EDC, New York, NY, U.S.A.) was immobilized by aggregation and cross-linking and subsequently used in the production of lactulose (Guerrero and others 2015a). The immobilized biocatalyst was prepared through protein precipitation with ammonium sulfate followed by cross-linking with glutaraldehyde. Lactulose synthesis was evaluated for free and immobilized enzyme, showing that the immobilization produced a positive change in product distribution, favoring the synthesis of lactulose over higher oligosaccharides obtained from lactose or lactulose. Furthermore, high fructose-to-lactose ratios clearly favored lactulose formation. Nevertheless, in repeated-batch operations (10 batches), when enzyme inactivation has to be considered, a lower fructose-to-lactose ratio was found to be a better condition. Although it represented a sacrifice in yield and productivity, enzyme stability was improved. Replacement of the biocatalyst at $50 \%$ residual activity and operation at lower fructose/lactose molar ratio can lead to a total of 98 repeated batches, which represents a considerable reduction in enzyme consumption and production costs.

\section{Lactulose as a Substrate of Other Enzymatic Reactions}

Besides its ability to undergo hydrolysis, lactulose can also act as the substrate in other enzymatic reactions, such as transglycosylation (donor/acceptor) to produce several lactulose-based oligosaccharides (novel prebiotic candidates) or alcoholic glycosides; and esterification to create sugar esters. All these reactions have particular interest for the food industry, either because they are the bases of useful methodologies for lactulose determination in dairy products, or because they lead to the formation of new compounds with interesting properties for food applications. Table 3 contains some examples of the use of lactulose as a substrate in enzymatic conversion, together with the corresponding products formed and biocatalysts used.

\section{Hydrolysis}

Being a prebiotic, lactulose is not expected to be degraded by mammalian intestinal enzymes. However, it is not completely resistant to other hydrolases of microbial origin. As mentioned before, lactulose can be hydrolyzed by the same enzyme that catalyzes its synthesis, which clearly compromises the yields and productivity of the bioprocess (van Rantwijk and others 1999). Mayer and others (2004) compared the kinetic constants for lactose and lactulose hydrolysis by $\beta$-galactosidase from $P . f u$ riosus and $A$. oryzae, and they found that both enzymes have higher affinity for lactulose than for lactose. Consequently, lactulose concentration can be affected by the occurrence of product hydrolysis as the lactose concentration progressively decreases during the biotransformation. On the other hand, in the presence of both disaccharides (lactulose and lactose), $\beta$-galactosidase from $B$. circulans hydrolyzed preferentially lactose instead of lactulose (Corzo-Martínez and others 2013). The intensity of lactulose hydrolysis is dependent on the microbial origin of the enzyme (Mayer and others 1996), as well as the reaction conditions, such as temperature and substrate concentration. These facts were recently demonstrated in a comparative study on the hydrolytic activity of several $\beta$-galactosidases from commercial preparations of $A$. oryzae, Aspergillus niger, Aspergillus aculeatus, $B$. circulans, and K. lactis, using lactulose as substrate (Guerrero and others 2015b).

A complete thermodynamic study about the hydrolysis of the galactose-fructose $(1 \rightarrow 4)$ linkage present in lactulose was reported by Tewari and Goldberg (1991) using a commercial microbial $\alpha$-galactosidase as catalyst. For the reaction:

$$
\text { Lactulose }+\mathrm{H}_{2} \mathrm{O} \rightarrow \mathrm{D}-\text { galactose }+\mathrm{D}-\text { fructose }
$$

the equilibrium constant $(128 \pm 10)$, the Gibbs energy $(-12.03$ $\pm 0.15)$, the enthalpy $(2.21 \pm 0.10 \mathrm{~kJ} / \mathrm{mol})$, and entropy $(47.8 \pm$ $0.5 \mathrm{~J} / \mathrm{mol} / \mathrm{K})$ changes were determined at room temperature and compared with other disaccharides.

The propensity of lactulose to be hydrolyzed by some microbial $\alpha$-galactosidases has been explored in several enzymatic methodologies developed to determine and quantify lactulose, mainly in milk samples. Generally, the procedure involves a dual-enzymatic system comprised a $\beta$-galactosidase to hydrolyze lactulose and a fructose dehydrogenase to oxidize the released $\mathrm{D}$-fructose to 5-keto-D-fructose. This oxidation can be mediated by an electron acceptor such as ferricyanide (Mayer and others 1996; Moscone and others 1999) or cause the reduction of the fructose dehydrogenase itself (Sekine and others 1998). In both cases, a subsequent reoxidation will generate a current proportional to the fructose concentration. Alternatively, an enzymatic spectrophotometric method using the same dual-enzymatic system ( $\beta$-galactosidase + fructose dehydrogenase) in the presence of a tetrazolium salt has been reported. In this case, a colored compound is formed and detected spectrophotometrically (Amine and others 2000; Marconi and others 2004).

The success of these enzymatic assays depends on the ability of the enzyme to hydrolyze lactulose. $\beta$-Galactosidase from $A$. oryzae has high hydrolytic activity for this disaccharide, and therefore, it is generally the enzyme chosen in this kind of methodology (Mayer and others 1996). However, based on the results obtained recently by Guerrero and others (2015b), $\beta$-galactosidase from $K$. lactis is also a good candidate for the enzymatic assays of lactulose determination.

The hydrolytic activity is also an important characteristic in the production of lactulose-based oligosaccharides as discussed in the following section. 
Table 3-Lactulose as substrate in different enzymatic reactions, together with the corresponding products formed and biocatalysts used.

\begin{tabular}{|c|c|c|c|}
\hline Enzyme & Substrate & Product & Reference \\
\hline \multicolumn{4}{|c|}{ Hydrolysis } \\
\hline \multirow{2}{*}{$\begin{array}{l}\beta \text {-Galactosidase from } P \text {. furiosus, } \\
\text { A. oryzae, } A \text {. niger, } A \text {. aculeatus, } \\
\text { B. circulans, and } K \text {. lactis }\end{array}$} & Lactulose & Galactose and fructose & Tewari and Goldberg (1991); \\
\hline & & & $\begin{array}{l}\text { Marconi and others }(2004) ; \\
\text { Mayer and others }(2004) ; \\
\text { Guerrero and others }(2015 b)\end{array}$ \\
\hline \multicolumn{4}{|c|}{ Transglycosylation } \\
\hline $\begin{array}{l}\beta \text {-Galactosidase from } T . \\
\text { aquaticus, } A \text {. Aculeatus, } K \\
\text { marxianus, } K \text {. lactis, } A \text {. oryzae, } \\
\text { B. circulans, and Lactobacillus } \\
\text { plantarum }\end{array}$ & Lactulose & $\begin{array}{l}\beta \text {-Galactooligosaccharides } \\
\text { ( } \beta \text {-GOSLu) including } \\
\text { 6'galactosyl-lactulose, } \\
\text { 3'galactosyl-lactulose, } \\
\text { 4'galactosyl-lactulose, } \\
\text { 1-galactosyl-lactulose, and } \\
\text { larger unidentified } \\
\text { oligosaccharides }\end{array}$ & $\begin{array}{l}\text { Berger and others (1995); } \\
\text { Martínez-Villaluenga and } \\
\text { others (2008); Cardelle-Cobas } \\
\text { and others (2008a); } \\
\text { Corzo-Martínez and others } \\
\text { (2013); Padilla and others } \\
\text { (2012); Guerrero and others } \\
\text { (2013); Benavente and others } \\
(2015) \text {. }\end{array}$ \\
\hline $\begin{array}{l}\text { Dextransucrase from Leuconostoc } \\
\text { mesenteroides }\end{array}$ & Lactulose and sucrose & $\begin{array}{l}\text { Glucooligosaccharides (GluOSLu) } \\
\text { Lactulosucrose }\end{array}$ & $\begin{array}{l}\text { Suzuki and Hehre (1964); Hehre } \\
\text { and Suzuki (1966); } \\
\text { Díez-Municio and others } \\
\text { (2012); Bivolarski and others } \\
\text { (2013) }\end{array}$ \\
\hline $\begin{array}{l}\alpha \text {-Galactosidase from Aspergillus } \\
\quad \text { nidulans expressed in E. coli }\end{array}$ & $\begin{array}{l}\text { Lactulose and 4-nitrophenyl } \\
\alpha \text {-D-Galactopyranoside }\end{array}$ & $\begin{array}{l}\alpha \text {-Galactooligosaccharides } \\
(\alpha \text {-GOSLu) }\end{array}$ & $\begin{array}{l}\text { Nakai and others (2010); Ryu and } \\
\text { others (2013) }\end{array}$ \\
\hline $\begin{array}{l}\text { Enzyme-couple reaction with } \\
\text { trehalose synthase and uridine } \\
\text { diphosphate glucose } \\
\text { 4-epimerase from Pyrococcus } \\
\text { horikoshii, and recombinant } \\
\alpha-1,3 \text { - or } \alpha-1,4 \text {-galactosyl- } \\
\text { transferase }\end{array}$ & $\begin{array}{l}\text { Lactulose and uridine } \\
\text { diphosphate-galactose }\end{array}$ & & \\
\hline $\begin{array}{l}\alpha \text {-Mannosidase from Canavalia } \\
\text { ensiformis } \\
\alpha-1,2 \text { - and } \alpha \text {-mannosidase from } \\
\text { Aspergillus phoenicis }\end{array}$ & Lactulose and mannose & $\begin{array}{l}\text { Mannooligosaccharides } \\
\text { (ManOSLu) }\end{array}$ & Suwasono and Rastall (1998) \\
\hline \multicolumn{4}{|c|}{ Transglycosylation } \\
\hline $\begin{array}{l}\alpha-1,3 \text {-fucosyltransferase from } \\
\text { Helicobacter pylori expressed } \\
\quad \text { in E. coli }\end{array}$ & $\begin{array}{l}\text { Lactulose and guanosine } \\
5^{\prime} \text {-diphospho- } \beta \text {-L-fucose } \\
\text { (GDP- } \beta \text {-fucose) }\end{array}$ & Fucooligosaccharides (FucOSLu) & Dumon and others (2001) \\
\hline $\begin{array}{l}\beta \text {-Xylosidase from Aspergillus } \\
\text { nidulans expressed in } \\
\quad \text { P. pastoris }\end{array}$ & $\begin{array}{l}\text { Lactulose and 4-nitrophenyl } \\
\beta \text {-D-xylopyranoside }\end{array}$ & Xylosyl-oligosaccharides (XOSLu) & Dilokpimol and others (2011) \\
\hline $\begin{array}{l}\beta \text {-Galactosidase from } A \text {. oryzae, } \\
\text { K. fragilis, K. lactis, and } A \text {. } \\
\text { aculeatus }\end{array}$ & Lactulose and glycerol & $\begin{array}{l}\text { 1-O- } \beta \text {-D-Galactopyranosyl- } \\
\text { glycerol, } \\
\text { 2-O- } \beta \text {-D-galactopyranosyl- } \\
\text { glycerol, and } \\
\text { galactopyranosyl- } \\
\text { galactopyranosyl-glycerol }\end{array}$ & $\begin{array}{l}\text { Woudenberg-van Oosterom and } \\
\text { others (1998); Hernandéz- } \\
\text { Hernandéz and others (2011) }\end{array}$ \\
\hline \multicolumn{4}{|c|}{ Esterification } \\
\hline $\begin{array}{l}\text { Lipase from Pseudomonas stutzeri } \\
\text { and Alcaligenes sp. }\end{array}$ & Lactulose and palmitic acid & Lactulose palmitate & Bernal and others $(2014,2015)$ \\
\hline $\begin{array}{l}\text { Protease from Bacillus } \\
\text { licheniformis or Lipase from } \\
\text { Candida antarctica }\end{array}$ & $\begin{array}{l}\text { Lactulose and trifluoroethyl } \\
\text { butanoate or ethyl butanoate }\end{array}$ & Lactulose butyrate & $\begin{array}{l}\text { Riva and others (1998); van der } \\
\text { Heijden and others (1998) }\end{array}$ \\
\hline
\end{tabular}

Transglycosylation to obtain oligosaccharides derived from lactulose (OSLu)

$\beta$-Galactooligosaccharides derived from lactulose $(\beta$-GOSLu). Similarly to lactose, lactulose can play the role of donor and acceptor in the formation of oligosaccharides. In the hydrolysis reaction, it acts as donor of the galactosyl moiety, but in the subsequent transfer reaction it is the acceptor of the residue which allows the synthesis of a new kind of GOS compounds, the lactulosebased galactooligosaccharides ( $\beta$-GOSLu), also called fructosylgalactooligosaccharides (fGOS) (Guerrero and others 2013). The mechanism proposed for $\beta$-GOSLu synthesis is similar to that described for GOS formation and involves the binding of 1 molecule of lactulose to the enzyme, while 1 molecule of fructose is released. The galactosyl-enzyme intermediate so formed reacts with another molecule of lactulose leading to the formation of a trisaccharide ( $\beta$-GOSLu-3). This trisaccharide can also be the acceptor of the galactosyl moiety from galactosyl-enzyme intermediate to form a tetrasaccharide ( $\beta$-GOSLu-4), and so on, creating larger oligosaccharides (Guerrero and others 2013).

The 1st studies reporting the formation of $\beta$-GOSLu were performed by Berger and others $(1995,1997)$ when characterizing the thermophilic $\beta$-galactosidase from Thermus aquaticus. The enzymatic synthesis was carried out at $\mathrm{pH} 7.0,70{ }^{\circ} \mathrm{C}$, and with $50 \mathrm{~g} / \mathrm{L}$ lactulose, and after $24 \mathrm{~h}$ some oligosaccharides were detected $(10 \%$ to $20 \%)$ but not identified. The actual use of lactulose, instead of lactose, as a precursor for the synthesis of $\beta$-GOSLu was only later investigated in a series of pioneering experiments using commercial $\beta$-galactosidases. The hydrolysis and subsequent transgalactosylation of lactulose has been demonstrated for $\beta$-galactosidase from $K$. lactis, $A$. aculeatus, $A$. oryzae, $A$. niger, and $B$. circulans under suitable conditions (Martínez-Villaluenga and others 2008; Cardelle-Cobas and others 2008a; HernandézHernandéz and others 2011; Guerrero and others 2013, 2015a). The yields and composition of the GOSLu obtained were mainly 
dependent on the balance between hydrolytic and transgalactosylation activities of the biocatalyst used. Nevertheless, operating conditions such as temperature, $\mathrm{pH}$, substrate concentration, and enzyme amount can also affect the results.

Lactulose conversion by commercial $\beta$-galactosidase from K. lactis (Lactozym $3000 \mathrm{~L} \mathrm{HP} \mathrm{G}$, Novozymes) at $50{ }^{\circ} \mathrm{C}, \mathrm{pH}$ $6.5,250 \mathrm{~g} / \mathrm{L}$ substrate, and $3 \mathrm{U} / \mathrm{mL}$ of enzyme, produced a mixture of monosaccharides (galactose and fructose), disaccharides (nonconverted lactulose and $\beta$-(1 $\rightarrow 6)$-galactobiose), and 2 novel trisaccharides which were fully characterized by nuclear magnetic resonance (RMN) (Martínez-Villaluenga and others 2008). For each trisaccharide an equilibrium mixture of 3 isomers was obtained and the major constituents were identified as $\beta$-D-Galactopyranosyl- $(1 \rightarrow 6)-\beta$-D-galactopyranosyl-( $1 \rightarrow 4)$ $\beta$-D-fructopyranose, also known as 6' galactosyl-lactulose (9.4 g/ $100 \mathrm{~g}$ of total carbohydrates after $6 \mathrm{~h}$ ); and $\beta$-D-Galactopyranosyl$(1 \rightarrow 4)-\beta$-D-fructopyranosyl-(1 $\rightarrow 1)-\beta$-D-galactopyranose, also known as 1-galactosyl-lactulose $(7.6 \mathrm{~g} / 100 \mathrm{~g}$ of total carbohydrates after $2 \mathrm{~h})$. The $\beta$ - $(1 \rightarrow 6)$ glycosidic linkage observed in 6 'galactosyl-lactulose was previously detected in GOS produced from lactose using $\alpha$-galactosidase from $K$. lactis, but the $\beta$ - $(1 \rightarrow 1)$ glycosidic linkage present in the other trisaccharide was reported for the 1 st time. After optimizing the reaction conditions $(\mathrm{pH}$ $6.5,50{ }^{\circ} \mathrm{C}, 2 \mathrm{~h}, 250 \mathrm{~g} / \mathrm{L}$ lactulose, and $6 \mathrm{U} / \mathrm{ml}$ of enzyme), the amount of trisaccharides obtained increased up to $10.4 \mathrm{~g} / 100 \mathrm{~g}$ of total carbohydrates for $6^{\prime}$ galactosyl-lactulose and $11.5 \mathrm{~g} / 100 \mathrm{~g}$ of total carbohydrates for 1-galactosyl-lactulose (Cardelle-Cobas and others 2011a). It was also observed that parameters such as temperature, lactulose, and enzyme concentration exerted a notable effect on the amount of the trisaccharides formed, with 6'galactosyllactulose more resistant to hydrolysis than 1-galactosyl-lactulose. The inhibitory effect of galactose and fructose in the synthesis of GOSLu was also observed, particularly from fructose (CardelleCobas and others 2011a). In a different study, the presence of small amounts of tetrasaccharides in the carbohydrate mixture derived from lactulose conversion by $\beta$-galactosidase from $K$. lactis was also detected; nevertheless, the structures of the $\beta$-GOSLu were not identified (Hernandéz-Hernandéz and others 2011).

The carbohydrate mixture resulting from the synthesis of $\beta$-GOSLu with commercial $\beta$-galactosidase from $A$. aculeatus (Pectinex ultra SP-L, Novozymes) presented some differences in the oligosaccharide composition, in contrast to the results obtained with $K$. lactis. Under the optimal reaction conditions $\left(60{ }^{\circ} \mathrm{C}, \mathrm{pH} 6.5,450 \mathrm{~g} / \mathrm{L}\right.$ substrate, and $16 \mathrm{U} / \mathrm{mL}$ of enzyme, $7 \mathrm{~h}$ of reaction), the trisaccharide 6 ' galactosyl-lactulose $(15 \mathrm{~g} / 100 \mathrm{~g}$ of total carbohydrates) was the major $\beta$-GOSLu formed (CardelleCobas and others). Nevertheless, 1-galactosyl-lactulose and some oligosaccharides with degree of polymerization $\geq 3$ were also detected (but not identified). The formation of tri-, tetra-, and pentasaccharides from lactulose transgalactosylation was also reported by Hernandéz-Hernandéz and others (2011). Studies on the inhibitory effect of monosaccharides resulting from lactulose hydrolysis revealed that galactose presented a stronger inhibition than fructose in $\beta$-GOSLu synthesis by $\beta$-galactosidase from $A$. aculeatus (Cardelle-Cobas and others 2008a). To better understand the mechanism of the enzymatic transglycosylation reaction during lactulose hydrolysis, Rodríguez-Fernandez and others (2011) developed a mathematical model mainly focused on the formation of 6 'galactosyl-lactulose and 1-galactosyl-lactulose by commercial $\beta$-galactosidase from $K$. lactis and $A$. aculeatus. The kinetic model showed good correlation between experimental and predicted data and provided important insights about the interaction between the enzyme and substrate at different temperature and substrate concentrations. The kinetic parameters describing the reversible oligosaccharide synthesis were of different magnitudes for both $\alpha$-galactosidases, since they produced mixtures with different compositions of oligosaccharides. The formation of trisaccharide was favored when using $\beta$-galactosidase from $A$. aculeatus, while the formation of disaccharides was superior when using $\beta$ galactosidase from $K$. lactis. Additionally, for $\alpha$-galactosidase from $A$. aculeatus, the synthesis of trisaccharides was increased at high temperatures, whereas disaccharide synthesis was larger at lower temperatures. On the other hand, for $\beta$-galactosidase from $K$. lactis the production of di- and trisaccharides was higher for the minimum temperature tested $\left(40{ }^{\circ} \mathrm{C}\right)$, which was also observed by Guerrero and others (2013).

The use of $\beta$-galactosidase from $A$. oryzae (Sigma) in the synthesis of $\beta$-GOSLu ( $\mathrm{pH} 6.5,50{ }^{\circ} \mathrm{C}, 450 \mathrm{~g} / \mathrm{L}$ lactulose, $16 \mathrm{U} / \mathrm{mL}$ of enzyme, and $1 \mathrm{~h}$ of reaction), originated a complex mixture formed by monosaccharides (30\%), lactulose (20\%), $\beta$ $(1 \rightarrow 6)$-galactobiose $(3 \%)$, allolactulose $(\beta-(1 \rightarrow 6)$ linkage $)(1 \%)$ 6 'galactosyl-lactulose $(20 \%)$, and other unidentified oligosaccharides (26\%) (Cardelle-Cobas 2009). In a later study, a characterization of the carbohydrate mixture was performed and additional compounds were identified (Hernandéz-Hernandéz and others 2011). The disaccharide fraction was composed of lactulose and several galactosyl-galactoses and galactosyl-fructoses. For the trisaccharide fraction, besides 6 'galactosyl-lactulose, the presence of 1-galactosyl-lactulose was also confirmed. Furthermore, tetra-, penta-, and hexasacharides were also found in the mixture. Guerrero and others (2013) reported the presence of tri- and tetrasaccharides as the main products of $\beta$-GOSLu synthesis when the reaction was carried out using commercial $\beta$-galactosidase from $A$. oryzae (Enzeco Fungal Lactase concentrate, EDC) under different conditions $\left(40{ }^{\circ} \mathrm{C}, \mathrm{pH} 4.5,400 \mathrm{~g} / \mathrm{L}\right.$ lactulose, and $200 \mathrm{U} / \mathrm{g}$ of substrate). Galactose was once more identified as a stronger inhibitor and the increase of temperature caused a decrease in the $\beta$-GOSLu synthesis. The $\beta$-GOSLu yield obtained (approximately $40 \%$ ) was significantly higher than those obtained with $\beta$-galactosidase from $K$. lactis and $B$. circulans. The $\beta$-GOSLu synthesis by $\beta$-galactosidase from $B$. circulans (Biolactasa-NTL, Biocon) under the same conditions, except for $\mathrm{pH}$ (4.5), presented a yield of only $14 \%$, with the carbohydrate mixture mainly composed of disaccharides (Guerrero and others 2013). The study of the hydrolytic and transgalactosylation activities of several commercial $\beta$-galactosidase preparations obtained from different sources and suppliers (A. oryzae, $A$. niger, $A$. aculeatus, B. circulans, and $K$. lactis) demonstrated the tendency of $K$. lactis for hydrolysis and the potential of $A$. oryzae and B. circulans for transgalactosylation. However, the transfer activity of $B$. circulans was higher for lactose than for lactulose, thus suggesting its suitability in GOS synthesis rather than $\beta$-GOSLu (Guerrero and others 2015b).

Besides the use of commercial enzymatic preparations, the synthesis of $\beta$-GOSLu was also reported for $\beta$-galactosidases obtained from crude cell extracts of Kluyveromyces strains isolated from artisanal cheese (Padilla and others 2012) and $\alpha$-galactosidase from Lactobacillus plantarum overexpressed in E. coli (Benavente and others 2015). The use of $\beta$-galactosidase from L. plantarum involved its prior immobilization via multipoint covalent attachment on glyoxyl-agarose, which significantly increased its stability. The carbohydrate mixture obtained at $\mathrm{pH} 5.0,45^{\circ} \mathrm{C}$, $450 \mathrm{~g} / \mathrm{L}$ lactulose, and $1 \mathrm{~g}$ of derivative containing $5 \mathrm{U} / \mathrm{mL}$, was composed of monosaccharides, $\beta$ - $(1 \rightarrow 6)$-galactobiose, lactulose, $6^{\prime}$ galactosyl-lactulose ( $8.5 \mathrm{~g} / 100 \mathrm{~g}$ of total carbohydrate), 
1-galactosyl-lactulose (9.5 g/100 g of total carbohydrate), a new trisaccharide identified as $3^{\prime}$ galactosyl-lactulose $(9 \mathrm{~g} / 100 \mathrm{~g}$ of total carbohydrate), and other unidentified $\beta$-GOSLu ( $5 \mathrm{~g} / 100 \mathrm{~g}$ of total carbohydrate) (Benavente and others 2015). On the other hand, the synthesis of $\beta$-GOSLu by $\alpha$-galactosidases from crude cell extracts of $K$. lactis and $K$ marxianus, under the conditions described by Martínez-Villaluenga and others (2008), led to the identification of only 2 trisaccharides, 6'galactosyl-lactulose, 1galactosyl-lactulose (Padilla and others 2012). The carbohydrate profile obtained was similar for all the strains tested containing monosaccharides, allolactulose, lactulose, $\beta$-(1 $\rightarrow 6)$-galactobiose, 2 unidentified di- or trisaccharides, and other higher oligosaccharides, besides the above-mentioned trisaccharides. In general, the trisaccharide formation predominated over the formation of the disaccharide $\beta$ - $(1 \rightarrow 6)$-galactobiose and the maximum production of $6^{\prime}$ galactosyl-lactulose (13 g/100 g of total carbohydrate) and 1-galactosyl-lactulose (17 g/100 g of total carbohydrate) was achieved using a $K$. marxianus strain.

Recently, these Kluyveromyces strains were also reported in the synthesis of $\beta$-GOSLu using a different strategy involving 2 steps: 1st, $\beta$-galactosidases from Kluyveromyces acted as catalysts in the formation of GOS mixtures by transgalactosylation of lactose from cheese whey permeate, and later sodium aluminate was used as catalyst in the isomerization of the GOS mixture to obtain $\beta$-GOSLu (Padilla and others 2015). Besides the formation of $\beta$-GOSLu (16 to $18 \mathrm{~g} / 100 \mathrm{~g}$ of total carbohydrate), this approach led to the production of mixtures with higher concentration of prebiotic carbohydrates $(50 \mathrm{~g} / 100 \mathrm{~g}$ of total carbohydrate) and lower caloric value. Since the isomerization reaction also converted glucose to fructose (lower caloric value than glucose), galactose to tagatose (also reported as prebiotic (Luecke and Bell 2010)), lactose to lactulose, and allolactose to allolactulose, the mixture was enriched in prebiotic sugars while its glycemic index was reduced. The $\beta$-GOSLu obtained were formed by 6 ' galactosyl-lactulose, $4^{\prime}$ galactosyl-lactulose $(\beta$-D-Galactopyranosyl- $(1 \rightarrow 4)-\beta$-D-galactopyranosyl- $(1 \rightarrow 4)-\beta$ D-fructopyranose), and other oligosaccharides which could be derived from lactulose. A similar carbohydrate mixture and $\beta$-GOSLu composition, except the trisaccharide 4'galactosyllactulose, was obtained by Cardelle-Cobas and others (2008b) using this combination process with commercial $\beta$-galactosidase (Lactozym 3000 L HP G, Novozymes) and different sodium aluminate to lactose ratios. Corzo-Martínez and others (2013) also reported a 2 -step strategy to obtain $\beta$-GOSLu from the lactose present in cheese whey permeate, although with a different order in the conversion reactions. In this case, the lactose was 1st isomerized to lactulose using egg shell as the food-grade catalyst, and subsequently the mixture containing lactulose was transgalactosylated by commercial $\beta$-galactosidase from $B$. circulans (Biolactasa- NTL, Biocon). The final mixture obtained after optimization of the transgalactosylation reaction was composed by $50 \%$ of potentially prebiotic carbohydrates including tagatose, lactulose, GOS, and $\beta$-GOSLu with degrees of polymerization up to $4.4^{\prime}$ Galactosyllactulose was one of the trisacharides identified.

All these $\beta$-GOSLu structures represent a new type of compounds with new glycosidic connections that are likely to have improved prebiotic activity compared to lactulose or GOS. Sometimes the use of lactulose must be limited due to its laxative effects when consumed at high doses. Furthermore, it is known that lactulose fermentation occurs mainly in the proximal colon which results in uncomfortable gas production (Attar and others 1999). Oligosaccharides with a longer degree of polymerization are more slowly fermented and, therefore, they can reach more distant parts of the colon, which then produce increased beneficial effects within the gastrointestinal tract. Some $\beta$-GOSLu, namely, 4'galactosyl-lactulose, 6'galactosyllactulose, and 1-galactosyl-lactulose showed a positive effect on the growth of Lactobacillus, Streptococcus, and Bifidobacterium strains, with observed preference toward $\beta$-galactosyl residues $\beta(1-6)$ and $\beta(1-1)$ linked over those $\beta(1-4)$ linked (Cardelle-Cobas and others $2011 b)$. Additionally, some strains presented higher cell densities and speed of growth on 6' galactosyl-lactulose than on the equivalent compound obtained from lactose. Similarly, the amount of short-chain fatty acids (SCFA) generated during prebiotic fermentation by a mixed fecal microbiota was higher for $\beta$-GOSLu than for GOS (Cardelle-Cobas and others 2012). Tests performed in rats confirmed the resistance of a $\beta$-GOSLu mixture $(78 \%$ disaccharides and $14 \%$ trisaccharides) to gut digestion and their selective fermentation within the large intestine (Hernández-Hernández and others 2012; Marín-Manzano and others 2013). Additionally, stronger bifidogenic effect was observed in rats fed with $\beta$-GOSLu than with GOS (Hernández-Hernández and others 2012), and $\beta$ GOSLu showed a better anti-inflammatory profile than lactulose when tested in the trinitrobenzenesulfonic acid model of rat colitis (Algieri and others 2014). $\beta$-GOSLu also presented potential to be used in the prevention of interactions and excessive inflammatory responses on intestinal epithelial cells by bacterial pathogens (Laparra and others 2013), as well as in the enhancement of iron absorption by deficient rats (Laparra and others 2014). The safety of a mixture of OSLu was also verified in rats by administrating a daily dose of $2 \mathrm{mg} / \mathrm{kg}$ of body weight, which was well tolerated during the $28 \mathrm{~d}$ of the test (Anadón and others 2013). Finally, the stability of a $\beta$-GOSLu mixture $(18 \%$ disaccharides, $22 \%$ trisacharides, and $6 \%$ tretrasaccharides) during the processing of foods such as milk and apple juice was demonstrated, thus suggesting their potential incorporation in the industrial production of functional foods (López-Sanz and others 2015).

Glucooligosaccharides derived from lactulose (GluOSLu). The enzymatic synthesis of glucooligosaccarides is catalyzed by glucosyltransferases able to hydrolyze the glucosyl donor (generally sucrose) and transfer the glucosyl residue to a suitable acceptor. The use of lactulose as acceptor and consequent production of lactulose-based glucooligosaccarides (GluOSLu) have been reported in the literature (Table 3). Extracellular dextransucrase from Leuconostoc mesenteroides showed high transferase activity and was successfully used as biocatalyst in the synthesis of GluOSLu (Bivolarski and others 2013). Under optimal conditions ( $\mathrm{pH} 5.3$, $35^{\circ} \mathrm{C}$, and molecular ratio of sucrose/lactulose $=2$ ), unidentified GluOSLu with polymerization degrees of 3 , 4, and 5 were obtained in the proportion $4: 2: 1$, respectively. Dextransucrase from $L$. mesenteroides was also the catalyst in the synthesis of a specific trisaccharide, lactulosucrose ( $\beta$-D-galactopyranosyl- $(1 \rightarrow 4)-\beta$-Dfructofuranosyl-(2 $\rightarrow 1)-\alpha$-D-glucopyranoside), produced from sucrose and lactulose, as indicated in Eq. 2 (Suzuki and Hehre 1964; Hehre and Suzuki 1966):

$$
\text { Sucrose }+ \text { Lactulose } \leftrightarrow \text { Lactulosucrose }+ \text { Fructose }
$$

The synthesis of lactulosucrose occurs through the transfer of the glucosyl moiety from sucrose to the 2-hydroxyl group of the reducing unit of lactulose (Díez-Municio and others 2012). Under optimal conditions ( $\mathrm{pH} 5.2,30^{\circ} \mathrm{C}$, sucrose/lactulose concentration ratio of $300 / 300 \mathrm{~g} / \mathrm{L}, 1.6$ to $2.4 \mathrm{u} / \mathrm{mL}, 8 \mathrm{~h}$ ), lactulosucrose and a minor amount of tetra- and pentasaccharides, probably 
derived from lactulose, were obtained with 35\%, 2.5\%, and $1.4 \%$ yield, respectively. Reaction parameters, such as the concentration ratio of sucrose to lactulose, the concentration of enzyme, and time, had a significant impact on the lactulosucrose yield. High sucrose/lactulose ratios and reaction times negatively affected the yield of lactulosucrose, while high concentration of enzyme improved the yield. Lactulosucrose being a lactulose-based oligosaccharide is also a promising candidate for the prebiotic status. In fact, its bifidogenic effect and SCFA production during fermentation were already demonstrated (García-Cayuela and others 2014; Díez-Municio and others 2016). However, these data are only initial evaluations and additional studies in vitro and in vivo are necessary to validate lactulosucrose as a prebiotic.

Other lactulose-based oligosaccharides. Lactulose has been used as acceptor in several other transfer reactions producing new compounds which are also potential candidates for prebiotic status. Among these promising oligosaccharides are $\alpha$-galactooligosaccharides ( $\alpha$-GOSLu); mannooligosaccharides (ManOSLu); fucooligosaccharides (FucOSLu); and xylosyl-oligosaccharides (XOSLu) (Table 3). The transgalactosylation reaction catalyzed by $\beta$-galactosidase from Aspergillus nidulans expressed in $E$. coli led to the formation of a novel $\alpha$-GOSLu, the $\alpha$-Dgalactopyranosyl-( $1 \rightarrow 6)-\beta$-D-galactopyranosyl-( $1 \rightarrow 4)$-D-fructofuranose. This trisaccharide was produced from lactulose (acceptor) and 4-nitrophenyl $\alpha$-D-galactopyranoside (donor) with $38 \%$ yield (Nakai and others 2010). Other $\alpha$-GOSLu compounds were obtained through a 3-enzyme-coupled reaction (trehalose synthase and uridine diphosphate glucose 4-epimerase from Pyrococcus horikoshii, and recombinant $\alpha-1,3-$ or $\alpha-1,4$-galactosyltransferase) and using lactulose (acceptor) and uridine diphosphate-galactose (donor) as substrates (Ryu and others 2013). ManOSLu formation from lactulose (acceptor) and mannose (donor) was reported for 3 mannosidases ( $\beta$-mannosidase from Canavalia ensiformis, and $\alpha-1,2-$ and $\alpha$-mannosidase from Aspergillus phoenicis). The trisaccharides $\operatorname{Man} \alpha 1 \rightarrow 6 \mathrm{Gal} \beta 1 \rightarrow 4 \mathrm{Fru}$ and $\mathrm{Man} \alpha 1 \rightarrow 3 \mathrm{Gal} \beta 1 \rightarrow 4 \mathrm{Fru}$ were the major products generated by each catalyst. However, depending on the enzyme different amounts of the trisaccharides were synthesized. For $\alpha$-mannosidase from Canavalia ensiformis, Man $\alpha 1 \rightarrow 6 \mathrm{Gal} \beta 1 \rightarrow 4 \mathrm{Fru}$ was the main trisaccharide formed, while the $\alpha-1,2-$ mannosidase from $A$. phoenicis favored the formation of Man $\alpha 1 \rightarrow 3 \mathrm{Gal} \beta 1 \rightarrow 4 \mathrm{Fru}$. The $\beta$-mannosidase from $A$. phoenicis produced similar amounts of both trisaccharides (Suwasono and Rastall 1998). FucOSLu carrying fucose on the fructosyl residue of lactulose were synthesized by $\alpha-1,3-$ fucosyltransferase from Helicobacter pylori expressed in E. coli, using lactulose (acceptor) and the nucleotide sugar GDP- $\beta$-fucose (donor) as substrates (Dumon and others 2001). XOSLu (35\% yield) was obtained from lactulose (acceptor) and 4-nitrophenyl $\beta$-D-xylopyranoside (donor) using $\beta$-xylosidase from Aspergillus nidulans expressed in Pichia pastoris (Dilokpimol and others 2011). The majority of the XOSLu seemed to be trisaccharides; nevertheless, their structures were not revealed due to the complexity of the carbohydrate mixture generated.

Additionally, lactulose proved to be a suitable galactosyl donor in the transfer reactions involved in the production of alcoholic glycosides, such as galactopyranosyl-glycerol or digalactosylglycerol, with potential application as aroma precursors or emulsifiers (Woudenberg-van Oosterom and others 1998). These reactions can be catalyzed by different $\beta$-galactosidase (A. oryzae, K. fragilis, K. lactis, and A. aculeatus) and use glycerol as acceptor (Woudenberg-van Oosterom and others 1998; Hernandéz-Hernandéz and others 2011).

\section{Esterification}

The enzymatic synthesis of sugar fatty acid esters is achieved through an esterification reaction between a fatty acid $\left(\mathrm{RCO}_{2} \mathrm{H}\right)$, which acts as acyl donor, and a sugar $\left(\mathrm{C}_{n}\left(\mathrm{H}_{2} \mathrm{O}\right)_{n}\right)$, which acts as acyl acceptor (Gumel and others 2011):

$$
\mathrm{C}_{\mathrm{n}}\left(\mathrm{H}_{2} \mathrm{O}\right)_{\mathrm{n}}+\mathrm{RCO}_{2} \mathrm{H} \stackrel{\text { Enzyme }}{\longleftrightarrow} \mathrm{C}_{\mathrm{n}}\left(\mathrm{H}_{2} \mathrm{O}\right)_{\mathrm{n}-1}(\mathrm{OCOR})+\mathrm{H}_{2} \mathrm{O}
$$

Lipases are the most common biocatalysts involved in this kind of reaction, mainly due to their stability, wide substrate specificity, regiospecificity, and availability at reduced costs. In general, the synthesis is carried out in nonaqueous media, with low water activity, to drive the reaction toward the ester synthesis instead of ester hydrolysis. Glucose, fructose, maltose, sucrose, and lactose are some examples of sugars which have been successfully used in the synthesis of sugar esters with several acyl donors (Gumel and others 2011; Neta and others 2015). Sugar fatty acid esters are described as tasteless, odorless, biodegradable, nontoxic, and nonirritant. Additionally, they present high surface activity and emulsifying capacity. All these characteristics make them interesting compounds to the pharmaceutical and food industries, where they are widely used as biosurfactants and emulsifiers in the preparation and stabilization of several foods and cosmetics (Neta and others 2015). However, the potential of sugar fatty acid esters can even be enhanced through the synthesis of novel compounds with improved properties. Considering the fact that the number of carbon atoms of the fatty acids and the molecular size of the sugar moiety are important aspects to determine the hydrophilic/hydrophobic balance of the final product (Bernal and others 2015), there is a broad variety of available sugars and fatty acids which can be tested. An interesting alternative is the lactulose esters which allow the combination of the unique properties of prebiotics with the well-known features of fatty acids, such as antimicrobial activity and ability to form micelles in aqueous solutions. As far as we know, only 2 examples of lactulose esters (lactulose butyrate and lactulose palmitate) have been described in the literature (Table 3). The acylation of lactulose by ethyl butanoate was reported by van der Heijden and others (1998) using commercial immobilized lipase from Candida antarctica (Novo Nordisk). The reaction was carried out in tert-butyl alcohol under reflux, at $82{ }^{\circ} \mathrm{C}$, leading to $99 \%$ lactulose conversion after $24 \mathrm{~h}$ of reaction. Since in solution lactulose can exist as a mixture of 3 different configurations, each of them with 2 or 3 primary hydroxyl groups, a complex mixture of esters can be formed. This fact was confirmed at the end of the enzymatic synthesis, with detection of the presence of several monoesters and higher ester structures. Riva and others (1998) also obtained a lactulose butyrate (1-O-butanoyl lactulose) with $48 \%$ yield as a single monoester. The reaction was performed in anhydrous dimethylformamide, in the presence of activated ester trifluoroethyl butanoate, and using a commercial protease from Bacillus licheniformis (Subtilisin Carlsberg, Sigma) as catalyst. The lactulose ester obtained resulted from the regioselective acylation of the fructose C-1 hydroxyl from lactulose. Its structure was suggested by RMN analysis and confirmed by the catalytic action of a $\beta$-galactosidase, which converted lactulose butyrate into D-galactosidase and 1-O-butanoyl-D-fructose. The synthesis of lactulose palmitate from lactulose and palmitic acid was achieved using lipases from Acaligenes sp. and Pseudomonas stutzeri immobilized in 3 different supports: glyoxyl silica, octyl silica and octyl-glyoxyl cobonded silica (Bernal and others 2014). The reaction was carried out in acetone with $4 \%$ moisture, at $40{ }^{\circ} \mathrm{C}$, and followed by 
HPLC which detected the occurrence of 3 peaks during the esterification reaction. Nevertheless, only 1 monoester palmitate was possible to purify and identify. Based on the conversion of palmitic acid, the best results were obtained with Pseudomonas stutzeri lipase immobilized on octyl-glyoxyl silica (33\%) and octyl silica (29\%). The reaction conditions of lactulose palmitate synthesis were later optimized $\left(47^{\circ} \mathrm{C}\right.$ and 1:3 lactulose/palmitic acid molar ratio), leading to an improvement either for Pseudomonas stutzeri lipase immobilized on octyl-glyoxyl silica (38\%) or on octyl silica (48\%) (Bernal and others 2015).

\section{Future Perspectives}

Lactose derivatives with prebiotic effect, such as lactulose, are showing interesting new applications and, consequently, the demand for these compounds has significantly increased. Besides their importance at the medical level, the consumption of prebiotics in the form of functional food is part of the "healthy lifestyle" that modern society incessantly attempts to adopt. The incorporation of lactulose in food and beverages, in dietary supplements, and also in animal feed has contributed to the enhancement of its market, which should be followed by the development of efficient strategies of synthesis. The implementation of an enzymatic process at industrial level requires the application of suitable enzymes able to compete with the chemical catalysts. The enzyme cellobiose-2-epimerase proved to be a promising biocatalyst with the potential to be considered a clear option in the industrial synthesis of lactulose. Protein engineering can also play an important role in the improvement of lactulose yield by enzymatic synthesis. The production of new mutants with remarkable transglycosilation activity can be an important contribution to guide the synthesis toward the desired product. The potential of enzymatic synthesis is well-known either by its high specificity or environmental advantages. Therefore, it is foreseeable that enzymatic processes will overcome the manufacturing drawbacks of the prebiotic industry.

The possibility of using lactulose also as a substrate in enzymatic synthesis increases its interest and opens a new field of research, and the prebiotic area is a direct beneficiary of it. Since the chemical structures of prebiotics may affect their fermentation by probiotic microorganisms, there is an increased interest in obtaining new promising compounds with improved or novel activities. The production of oligosaccharides from lactulose opens the possibility of synthesis of new compounds which exhibit the same properties as lactulose. Furthermore, the formation of larger structures would enhance the beneficial effects within the gastrointestinal tract by the extension of colonic persistence and, at the same time, reduce the typical lactulose fermentation in the proximal colon which frequently results in uncomfortable gas production. The potential already demonstrated for some lactulose-based oligosaccharides allows their entrance into the prebiotic market with increased demand in the future. However, to reach that status, more clinical studies are needed to obtain robust data about their prebiotic effect both in humans and animals.

Lactulose esters are attractive biosurfactants and emulsifiers that allow combining the excellent properties of lactulose with the features of fatty acids. Their interest and application in the food and pharmaceutical industry could be increased if they can be regarded as interesting vehicles for delivering both lactulose and fatty acids.

\section{General Conclusions}

Lactulose production via the enzymatic route offers considerable advantages over chemical synthesis, mainly because enzymes pro- vide a cleaner production of this prebiotic. Two different types of enzymes can be used as biocatalysts, enzymes that catalyze lactose hydrolysis and also transgalactosylation reactions, like $\beta$ galactosidase; and enzymes that catalyze the isomerization of the glucosyl moiety in lactose to fructose, like cellobiose-2-epimerase. The best results reported for enzymatic synthesis of lactulose were obtained with cellobiose-2-epimerase. The use of lactulose as substrate for additional enzymatic synthesis allows producing novel and promising compounds, such as lactulose-based oligosaccharides or lactulose esters, which greatly improve the potential of lactulose. The optimal reaction conditions for lactulose production and conversion depend both on the type of enzyme and microbial source. In the same way, the product composition obtained at the end of the enzymatic reactions is strongly dependent on the biocatalyst used.

\section{Acknowledgments}

This study was supported by the Portuguese Foundation for Science and Technology (FCT) under the scope of the strategic funding of UID/BIO/04469/2013 unit and COMPETE 2020 (POCI01-0145-FEDER-006684). The authors also thank the FCT for the financial support under the scope of the Project RECI/BBBEBI/0179/2012 (FCOMP-01-0124-FEDER-027462). SCS also acknowledges her post doc grant (SFRH/BPD/88584/2012) from FCT.

\section{Conflicts of Interest}

The authors declare no conflicts of interest.

\section{Author Contributions}

S.C. Silvério conducted the literature search, proposed the outline of the review, and prepared the manuscript. E.A. Macedo and J.A. Teixeira made useful revisions of the manuscript. L.R. Rodrigues supervised the work, refined the information presented in the manuscript, and approved it for publication.

\section{References}

Adamczak M, Charubin D, Bednarski W. 2009. Influence of reaction medium composition on enzymatic synthesis of galactooligosaccharides and lactulose from lactose concentrates prepared from whey permeate. Chem Pap 63:111-6.

Adrio JL, Demain AL. 2014. Microbial enzymes: tools for biotechnological processes. Biomolecules 4:117-39.

Aider M, Gimenez-Vidal M. 2012. Lactulose synthesis by

electro-isomerization of lactose: effect of lactose concentration and electric current density. Innov Food Sci Emerg 16:163-70.

Aider M, Halleux D. 2007. Isomerization of lactose and lactulose production: review. Trends Food Sci Tech 18:356-64.

Ait Aissa A, Aider M. 2013a. Ion exchange membranes controlled electro-catalytic synthesis of lactulose from lactose under refrigerated conditions. Innov Food Sci Emerg 20:299-309.

Ait Aissa A, Aider M. 2013b. Lactose isomerization into lactulose in an electro-activation reactor and high-performance liquid chromatography (HPLC) monitoring of the process. J Food Engr 119:115-24.

Ait Aissa A, Aider M. 2014. Electro-catalytic isomerization of lactose into lactulose: The impact of the electric current, temperature and reactor configuration. Intl Dairy J 34:213-9.

Ajisaka K, Nishida H, Fujimoto H. 1987. Use of an activated carbon column for the synthesis of disaccharides by use of a reverse hydrolysis activity of $\beta$-galactosidase. Biotechnol Lett 9:387-92.

Algieri F, Rodríguez-Nogales A, Garrido-Mesa N, Vezza T, Garrido-Mesa J, Utrilla MP, Montilla A, Cardelle-Cobas A, Olano A, Corzo N, Guerra-Hernández E, Zarzuelo A, Rodriguez-Cabezas ME, Galvez J. 2014 Intestinal anti-inflamatory effects of oligosaccharides derived from lactulose in the trinitrobenzenesulfonic acid model of rat colitis. J Agric Food Chem 62:4285-97 
Amine A, Moscone D, Bernardo RA, Marconi E, Palleschi G. 2000. A new enzymatic spectrophotometric assay for the determination of lactulose in milk. Anal Chim Acta 406:217-24.

Anadón A, Martínez MA, Ares I, Castellano V, Martínez-Larranãga MR, Corzo N, Olano A, Montilla A, Recio I, Martínez-Maqueda D, Miralles B, Fornari T, García-Risco MR, Gonzalez M, Reglero G. 2013. Acute and repeated dose ( 28 days) oral safety studies of ALIBIRD in rats. J Food Protect 7:1226-39.

Attar A, Lémann M, Ferguson A, Halphen M, Boutron M-C, Flourié B, Alix E, Salmeron M, Guillemot F, Chaussade S, Ménard A-M, Naudin G, Barthet M. 1999. Comparation of a low dose polyethylene glycol electrolyte solution with lactulose for treatment of chronic constipation. Gut 44:226-30.

Benavente R, Pessela B, Curiel JA, de las Rivas B, Muñoz R, Guisán JM, Mancheño JM, Cardelle-Cobas A, Ruiz-Matute AI, Corzo N. 2015. Improving properties of a novel b-galactosidase from Lactobacillus plantarum by covalent immobilization. Molecules 20:7874-89.

Berger J-L, Lee BH, Lacroix C. 1995. Identification of new enzyme activities of several strains of Thermus species. Appl Microbiol Biotechnol 44:81-7.

Berger J-L, Lee BH, Lacroix C. 1997. Purification, properties and characterization of high-molecular-mass b-galactosidase isoenzyme from Thermus aquaticus YT-1. Biotechnol Appl Biochem 25:29-41.

Bernal C, Illanes A, Wilson L. 2014. Heteroctional hydrophilic-hydrophobic porous silica as support for multipoint covalent immobilization of lipases: application to lactulose palmitate synthesis. Langmuir 30:3557-66. Bernal C, Illanes A, Wilson L. 2015. Improvement of efficiency in the enzymatic synthesis of lactulose palmitate. J Agric Food Chem 63:3716-24. Bivolarski V, Vasileva T, Bozov P, Iliev I. 2013. Influence of different acceptors on the synthesis of glucooligosaccharides by purified dextransucrase from Leuconostoc Mesenteroides UR 13. CR Acad Bulg Sci 66:1405-12.

Cardelle-Cobas A. 2009. Síntesis, caracterización y estudio del carácter prebiótico de oligosacáridos derivados de la lactulosa [PhD thesis]. Universidade Autónoma de Madrid, Madrid.

Cardelle-Cobas A, Martínez-Villaluenga C, Villamiel M, Olano A, Corzo N. 2008a. Synthesis of oligosaccharides derived from lactulose and Pectinex Ultra SP-L. J Agric Food Chem 56:3328-33.

Cardelle-Cobas A, Corzo N, Villamiel M, Olano A. 2008b. Isomerization of lactose-derived oligosaccharides: a case study using sodium aluminate. J Agric Food Chem 56:10954-9.

Cardelle-Cobas A, Corzo N, Martínez-Villaluenga C, Olano A, Villamiel M. 2011a. Effect of reaction conditions on lactulose-derived trisaccharides obtained by transgalactosylation with $\beta$-galactosidase of Kluyveromyces lactis. Eur Food Res Technol 233:89-94.

Cardelle-Cobas A, Corzo N, Olano A, Peláez, Requena T, Ávila M. 2011b Galactooligosaccharides derived from lactose and lactulose: influence of structure on Lactobacillus, Streptococcus and Bifidobacterium growth. Intl J Food Microbiol 149:81-7.

Cardelle-Cobas A, Olano A, Corzo N, Villamiel M, Collins M, Kolida S, Rastall RA. 2012. In vitro fermentation of lactulose-derived oligosaccharides by mixed fecal microbiota. J Agric Food Chem 60:2024-32.

Carobbi R, Miletti S, Franci V, inventors. 1985. Isomerization in magnesium compound and sodium hydrosulfite. U.S. Patent 4536221 A.

Claeys WL, Ludikhuyze LR, Hendrickx ME. 2001. Formation kinetics of hydroxymethylfurfural, lactulose and furosine in milk heated under isothermal and non-isothermal conditions. J Dairy Res 68:287-301.

Corzo-Martínez M, Copoví P, Olano A, Moreno FJ, Montilla A. 2013. Synthesis of prebiotic carbohydrates derived from cheese whey permeate by a combined process of isomerisation and transgalactosylation. J Sci Food Agric 93:1591-7.

Díez-Municio M, Herrero M, Jimeno ML, Olano A, Moreno FJ. 2012. Efficient synthesis and characterization of lactulosucrose by Leuconostoc mesenteroides B-512F dextransucrase. J Agric Food Chem 60:10564-71. Díez-Municio M, Kolida S, Herrero M, Rastrall RA, Moreno FJ. 2016. In vitro faecal fermentation of novel oligosaccharides enzymatically synthesized using microbial transglycosidases action on sucrose. J Funct Foods 20:532-44.

Dilokpimol A, Nakai H, Gotfredsen CH, Appeldoorn M, Baumann MJ, Nakai N, Schols HA, Hachem MA, Svensson B. 2011. Enzymatic synthesis of $\beta$-xylosyl-oligosaccharides by transxylosylation using two $\beta$-xylosidases of glycoside hidrolase family 3 from Aspergillus nidulans FGSC A4. Carbohyd Res 346:421-9.
Dumon C, Priem B, Martin SL, Heyraud A, Bosso C, Samain E. 2001. In vivo fucosylation of lacto-N-neotetraose and lacto-N-neohexaose by heterologous expression of Helibacter pylori a-1,3 fucosyltransferase in engineered Escherichia coli. Glycoconjugate J 18:465-74.

Fattahi H, Ashtiani FZ, Bonakdarpour B, Hashemi SA, Khatami SH. 2010. Enzymatic synthesis of lactulose by commercial beta-galactosidase from Kluyveromyces lactis. Afinidad 67:149-53.

Feng H-Y, Drone J, Hoffmann L, Tran V, Tellier C, Rabiller C, Dion M. 2005. Converting a b-glycosidase in to a b-transglycosidase by direct evolution. J Biol Chem 280:37088-97.

Förster-Fromme K, Schuster-Wolff-Bühring R, Hartwig A, Holder A, Schwiertz A, Bischoff SC, Hinrichs J. 2011. A new enzymatically produced 1-lactulose: a pilot study to test the bifidogenic effects. Intl Dairy J 21:940-8. García-Cayuela T, Díez-Municio M, Herrero M, Martínez-Cuesta MC, Peláez C, Requena T, Moreno FJ. 2014. Selective fermentation of potential prebiotic lactose-derived oligosaccharides by probiota bacteria. Intl Dairy J 38:11-5.

Gibson GR, Probert HM, Loo JV, Rastall RA, Roberfroid MB. 2004.

Dietary modulation of the human colonic microbiota: updating the concept of prebiotics. Nutr Res Rev 17:259-75.

Gibson GR, Scott KP, Rastall RA, Tuohy KM, Hotchkiss A,

Dubert-Ferrandon A, Gareau M, Murphy EF, Saulnier D, Loh G, Macfarlane S, Delzenne N, Ringel Y, Kozianowski G, Dickmann R, Lenoir-Wijnkook I, Walker C, Buddington R. 2010. Dietary prebiotics: current status and new definition. In: Gibson GR, editor. Food science and technology bulletin: functional foods. Vol. 7. Reading: IFIS Publishing. p 1-19.

Gosling A, Stevens GW, Barber AR, Kentish SE, Gras SL. 2010. Recent advances refining galactooligosaccharide production from lactose. Food Chem 121:307-18.

Gu J, Yang R, Hua X, Zhang W, Zhao W. 2015. Adsorption-based immobilization of Caldicellulosiruptor saccharolyticus cellobiose 2-epimerase on Bacillus subtilis spores. Biotechnol Appl Biochem 62:237-44.

Guerrero C, Vera C, Plou F, Illanes A. 2011. Influence of reaction conditions on the selectivity of the synthesis of lactulose with microbial $\beta$-galactosidases. J Mol Catal B-Enzym 72:206-12.

Guerrero C, Vera C, Illanes A. 2013. Optimisation of synthesis of oligosaccharides derived from lactulose (fructosyl-galacto-oligosaccharides) with $\beta$-galactosidases from different origin. Food Chem 138:2225-32.

Guerrero C, Vera C, Araya E, Conejeros R, Illanes A. 2015a. Repeated-batch operation for the synthesis of lactulose with $\beta$-galactosidase immobilized by aggregation and crosslinking. Bioresour Technol 190:122-31.

Guerrero C, Vera C, Conejeros R, Illanes A. 2015b. Transgalactosylation and hydrolytic activities of commercial preparations of b-galactosidase for the synthesis of prebiotic carbohydrates. Enzyme Microb Tech 70:9-17.

Gumel AM, Annuar MSM, Heidelberg T, Chisti Y. 2011. Lipase mediated synthesis of sugar fatty acid esters. Process Biochem 46:2079-90.

Hajek J, Murzin DY, Salmi T, Mikkola J-P. 2013. Interconversion of lactose to lactulose in alkaline environment: comparison of different catalysis concepts. Top Catal 56:839-45.

Hashem AM, Ismail SAE, Helmy WA, El-Mohamady Y, Abou-Romia R. 2013. Factors affecting the production of lactulose by Lactobacillus acidophilus NRRL $4495 \beta$-galactosidase and its biological activity. Malays J Microbiol 9:1-6.

Hehre EJ, Suzuki H. 1966. New reactions of dextransucrase: $\alpha$-D-glucosyl transfer to and from the anomeric sites of lactulose and fructose. Arch Biochem Biophys 113:675-83.

van der Heijden AM, Zuijderduijn FJ, van Rantwijk F. 1998.

Transesterification of lactulose with ethyl butanoate catalysed by Candida antarctica lipase. J Mol Catal A: Chem 134:259-65.

Hennigan TW, Sian M, Matthews J, Allen-Mersh TG. 1995. Protective role of lactulose in intestinal carcinogenesis. Surg Oncol 4:31-4.

Hernández-Hernández O, Montañés F, Clemente A, Moreno FJ, Sanz ML. 2011. Characterization of galactooligosaccharides derived from lactulose. J Chrom A 1218:7691-6.

Hernández-Hernández O, Marín-Manzano MC, Rubio LA, Moreno FJ, Sanz ML, Clemente A. 2012. Monomer and linkage type of galacto-oligosaccharide affects their resistance to ileal digestion and prebiotic properties in rats. J Nutr 142:1232-9.

Hu XJ, Robin S, O'Connell S, Walsh G, Wall JG. 2010. Engineering of a fungal beta-galactosidase to remove product inhibition by galactose. Appl Microbiol Biotechnol 87:1773-82. 
Hua X, Yang R, Zhang W, Fei Y, Jin Z, Jiang B. 2010. Dual-enzymatic synthesis of lactulose in organic-aqueous two-phase media. Food Res Intl 43:716-22.

Hua X, Yang R, Shen Q, Ye F, Zhang W, Zhao W. 2013. Production of 1-lactulose and lactulose using commercial beta-galactosidase from Kluyveromyces lactis in the presence of fructose. Food Chem 137:1-7.

Khatami S, Ashtiani FZ, Bonakdarpour B, Mehrdad M. 2014. The enzymatic production of lactulose via transglycosylation in conventional and non-conventional media. Intl Dairy J 34:74-9.

Kim JE, Kim YS, Kang LW, Oh DK. 2012. Characterization of a recombinant cellobiose 2-epimerase from Dictyoglomus turgidum that epimerizes and isomerizes $\beta-1,4$ and $\alpha-1,4$-gluco-oligosaccharides. Biotechnol Lett 34:2061-8.

Kim YS, Oh DK. 2012. Lactulose production from lactose as a single substrate by a thermostable cellobiose 2-epimerase from Caldicellulosiruptor saccharolyticus. Bioresource Technol 104:668-72.

Kim YS, Park CS, Oh DK. 2006. Lactulose production from lactose and fructose by a thermostable $\beta$-galactosidase from Sulfolobus solfataricus. Enzyme Microb Tech 39:903-8.

Kim YS, Kim JE, Oh DK. 2013. Borate enhances the production of lactulose from lactose by cellobiose 2-epimerase from Caldicellulosiruptor saccharolyticus. Bioresource Technol 128:809-12.

Kozempel MF, Kurantz MJ, Craig JC, Hicks KB. 1995. Development of a continuous lactulose process: separation and purification. Biotechnol Progr 11:592-5.

Laparra JM, Hernández-Hernández O, Moreno FJ, Sanz Y. 2013. Neoglycoconjugates of caseinomacropeptide and galactooligosaccharides modify adhesion of intestinal pathogens and inflammatory response(s) of intestinal (Caco-2) cells. Food Res Intl 54:1096-102.

Laparra JM, Díez-Municio M, Herrero M, Moreno FJ. 2014. Structural differences of prebiotic oligosaccharides influence their capacity to enhance iron absorption in deficient rats. Food Funct 5:2430-7.

Lee YJ, Kim CS, Oh DK. 2004. Lactulose production by beta-galactosidase in permeabilized cells of Kluyveromyces lactis. Appl Miclobiol Biot 64:787-93.

Li Y, Lu L, Wang H, Xu X, Xiao M. 2009. Cell surface engineering of a beta-galactosidase for galactooligosaccharide synthesis. App Environ Microbiol. 75:5938-42.

López-Sanz S, Montilla A, Moreno FJ, Villamiel M. 2015. Stability of oligosaccharides derived from lactulose during the processing of milk and apple juice. Food Chem 183:64-71.

Lorenzen PC, Breiter J, Clawin-Rädecker I, Dau A. 2013. A novel bi-enzymatic system for lactose conversion. Intl J Food Sci Tech 48:1396-403

Luecke KJ, Bell LN. 2010. Thermal stability of tagatose in solution. J Food Sci 75:C346-51.

Manzi P, Pizzoferrato L. 2013. HPLC determination of lactulose in heat treated milk. Food Bioprocess Tech 6:851-7.

Marconi E, Messia MC, Amine A, Moscone D, Vernazza F, Stocchi F, Palleschi G. 2004. Heat-treated milk differentiation by a sensitive lactulose assay. Food Chem 84:447-50.

Marín-Manzano MC, Abecia L, Hernández-Hernández O, Sanz ML, Montilla A, Olano A, Rubio LA, Moreno FJ, Clemente A. 2013. Galacto-oligosaccharide derived from lactulose exert a selective stimulation on the growth of Bifidobacterium animalis in the large intestine of growing rats. J. Agric Food Chem 61:7560-7.

Martínez-Villaluenga C, Cardelle-Cobas A, Olano A, Corzo N, Villamiel M, Jimeno ML. 2008. Enzymatic synthesis and identification of tow trisaccharides produced from lactulose by transgalactosylation. J Agric Food Chem 56:557-63.

Mayer J, Conrad J, Klaiber I, Lutz-Wahl S, Beifuss U, Fischer L. 2004. Enzymatic production and complete nuclear magnetic resonance assignment of sugar lactulose. J Agric Food Chem 52:6983-90.

Mayer J, Kranz B, Fischer L. 2010. Continuous production of lactulose by immobilized thermostable beta-glycosidase from Pyrococcus furiosus. J Biotechnol 145:387-93.

Mayer M, Genrich M, Künnecke W, Bilitewski U. 1996. Automated determination of lactulose in milk using an enzyme reactor and flow analysis with integrated dialysis. Anal Chim Acta 324:37-45.

Montgomery EM, Hudson CS. 1930. Relations between rotatory power and structure in the sugar group. XXVII. Synthesis of a new disaccharide ketose (lactulose) from lactose. J Am Chem Soc 52:2101-6.

Montilla A, del Castillo MD, Sanz ML, Olano A. 2005. Egg shell as catalyst of lactose isomerisation to lactulose. Food Chem 90:883-90.
Morales FJ, Romero C, Jiménez-Pérez S. 2000. Characterization of industrial processed milk by analysis of heat-induced changes. Intl J Food Sci Tech 35:193-200.

Moscone D, Bernardo RA, Marconi E, Amine A, Palleschi G. 1999. Rapid determination of lactulose in milk by microdialysis and biosensors. Analyst 124:325-9.

Moulin G, Galzy P. 1984. Whey, a potential substrate for biotechnology.

Biotechnol Genet Engr 1:347-74.

Nagendra R, Viswanatha S, Kumar SA, Murthy BK, Rao SV. 1995. Effect of feeding milk formula containing lactulose to infants on faecal bifidocaterial flora. Nutr Res 15:15-24.

Nakai H, Baumann MJ, Petersen BO, Westphal Y, Hachem MA,

Dilokpimol A, Duus JØ, Schols HA, Svensson B. 2010. Aspergillus nidulans $\alpha$-galactosidase of glycoside hydrolase family 36 catalyses the formation of $\alpha$-galacto-oligosaccharides by transglycosylation. FEBS J 277:3538-51.

Neta NS, Teixeira JA, Rodrigues LR. 2015. Sugar ester surfactants: enzymatic synthesis and applications in food industry. Crit Rev Food Sci Nutr 55:595-610.

Nguyen TT, Nguyen HA, Arreola SL, Mlynek G, Djinovic-Carugo K, Mathiesen G, Nguyen TH, Haltrich D. 2012. Homodimeric beta-galactosidase from Lactobacillus delbrueckii subsp. bulgaricus DSM 20081: expression in Lactobacillus plantarum and biochemical characterization. J Agric Food Chem 60:1713-21.

Oliveira C, Guimarães PMR, Domingues L. 2011. Recombinant microbial systems for improved beta-galactosidase production and biotechnological applications. Biotechnol Adv 29:600-9.

Padilla B, Ruiz-Matute AI, Belloch C, Cardelle-Cobas A, Corzo N, Manzanares P. 2012. Evaluation of oligosaccharide synthesis from lactose and lactulose using $\beta$-galacosidase from Kluyveromyces isolated from artisanal cheeses. J Agric Food Chem 60:5134-41.

Padilla B, Frau F, Ruiz-Matute, Montilla A, Belloch C, Manzanares P, Corzo N. 2015. Production of lactulose oligosaccharides by isomerisation of transgalactosylated cheese whey permeate obtained by $\beta$-galactosidase from dairy Kluyveromyces. J Dairy Res 82:356-64.

Parrish FW, inventor. 1970. Isomerization of glucose, maltose, and lactose with amino compounds. U.S. Patent 3514327 A.

Pawlak-Szukalska A, Wanarska M, Popinigis AT, Kur J. 2014. A novel cold-active $\beta$-D-galactosidase with transglycosylation activity from the Antarctic Arthrobacter sp. 32cB-gene cloning, purification and characterization. Process Biochem 49:2122-33.

Playne MJ, Crittenden RG. 2009. Galacto-oligosaccharides and others products derived from lactose. In: McSweeney PLH, Fox PF, editors. Advanced dairy chemistry. Vol. 3: lactose, water, salts and minor constituents. 3rd ed. New York, N.Y.: Springer. p 121-201.

van Rantwijk F, Woudenberg-van Oosterom M, Sheldon RA. 1999. Glycosidase-catalysed synthesis of alkyl glycosides. J Mol Catal B: Enzym 6:511-32.

Riva S, Nonini M, Ottolina G, Danieli B. 1998. Subtilisin-catalyzed esterification of di- and oligosaccharides containing a D-fructose moiety. Carbohydr Res 314:259-66.

Rodriguez-Fernandez M, Cardelle-Cobas A, Villamiel M, Banga JR. 2011. Detailed kinetic model describing new oligosaccharides synthesis using different $\beta$-galactosidases. J Biotechnol 153:116-24.

Ryu S-I, Woo J-B, Lee S-B. 2013. Coupling reactions of trehalose synthase from Pyrococcus horikoshii: cost-effective synthesis and anti-adhesive activity of a-galactosyl oligosaccharides using a one-pot three-enzyme system with trehalose. Bioresource Technol 136:743-6.

Schumann C. 2002. Medical, nutritional and technological properties of lactulose. An update. Eur J Nutr 41:I17-25.

Schüürmann J, Quehl P, Festel G, Jose J. 2014. Bacterial whole-cell biocatalysts by surface display of enzymes: toward industrial application. Appl Microbiol Biotechnol 98:8031-46.

Seki N, Hamano H, Iiyama Y, Asano Y, Kokubo S, Yamauchi K, Tamura Y, Uenishi K, Kudou H. 2007. Effect of lactulose on calcium and magnesium absorption: a study using stable isotopes in adult man. J Nutr Sci Vitaminol 53:5-12.

Sekine Y, Hall EAH. 1998. A lactulose sensor based on coupled enzyme reactions with a ring electrode fabricated from etrathiafulvalen-tetracyanoquinodimetane. Biosens Bioelectron 13:995-1005.

Shen Q, Yang R, Hua X, Ye F, Wang H, Zhao W, Wang K. 2012. Enzymatic synthesis and identification of oligosaccharides obtained by transgalactosylation of lactose in the presence of fructose using beta-galactosidase from Kluyveromyces lactis. Food Chem 135:1547-54. 
Shukla R, Verykios XE, Mutharasan R. 1985. Isomerization and hydrolysis reactions of important disaccharides over inorganic heterogeneous catalysts. Carbohyd Res 143:97-106.

Sirec T, Strazzulli A, Isticato R, de Felice M, Moracci M, Ricca E. 2012. Adsorption of $\beta$-galactosidase of Alicyclobacillus acidocaldarius on wild type and mutants spores of Bacillus subtilis. Micro Cell Fact 5:100.

Sitanggang AB, Drews A, Kraume M. 2014. Continuous synthesis of lactulose in an enzymatic membrane reactor reduces lactulose secondary hydrolysis. Bioresource Technol 167:108-15.

Sitanggang AB, Drews A, Kraume M. 2015. Influences of operating conditions on continuous lactulose synthesis in an enzymatic membrane reactor system: a basis prior to long-term operation. J Biotech 203:89-96.

Song YS, Lee JH, Kang SW, Kim SW. 2010. Performance of $\beta$-galactosidase pretreated with lactose to prevent activity loss during the enzyme immobilisation process. Food Chem 123:1-5.

Song YS, Shin HY, Lee JY, Park C, Kim SW. 2012.

$\beta$-Galactosidase-immobilised microreactor fabricated using a novel technique for enzyme immobilisation and its application for continuous synthesis of lactulose. Food Chem 133:611-7.

Song YS, Lee HU, Park C, Kim SW. 2013a. Batch and continuous synthesis of lactulose from whey lactose by immobilized beta-galactosidase. Food Chem 136:689-94.

Song YS, Lee HU, Park C, Kim SW. 2013b. Optimization of lactulose synthesis from whey lactose by immobilized beta-galactosidase and glucose isomerase. Carbohyd Res 369:1-5.

Song YS, Suh YJ, Park C, Kim SW. 2013c. Improvement of lactulose synthesis through optimization of reaction conditions with immobilized $\beta$-galactosidase. Korean J Chem Engr 30:160-5.

Suwasono S, Rastall RA. 1998. Enzymatic synthesis of manno- and heteromanno-oligosaccharides using a-mannosidases: a comparative study of linkage-specific and non-linkage-specific enzymes. J Chem Technol Biotechnol 73:37-42.

Suzuki H, Hehre EJ. 1964. Lactulosucrose ( $4^{\mathrm{F}}-\beta$-Galactosylsucrose), a new trisaccharide synthesized by cultures of Leuconostoc mesenteroides strain K (NRRL B-1299). Arch Biochem Biophys 105:339-48.

Szilagyi A. 2010. Functional disaccharides-lactulose, lactitol and lactose. In: Cho SS, Finocchiaro ET, editors. Handbook of prebiotics and probiotics ingredients - health benefits and food applications. Boca Raton, Fla.: CRC Press. p 95-122.
Tang L, Li ZA, Dong XX, Yang RJ, Zhang JH, Mao ZG. 2011. Lactulose biosynthesis by beta-galactosidase from a newly isolated Arthrobacter sp. J Ind Microbiol Biot 38:471-6.

Tewari YB, Goldberg RN. 1991. Thermodynamics of hydrolysis of disaccharides: lactulose, $\alpha-\mathrm{D}$-melibiose, palatinose, D-trehalose, D-turanose and 3-o- $\beta$-D-galactopyranosyl-D-arabinose. Biophys Chem 44:59-67.

Troyano E, De Rafael D, Martinez-Castro I, Olano A. 1996. Isomerization of lactose over natural sepiolite. J Chem Technol Biot 65:111-4.

Vaheri M, Kauppinen V. 1978. The formation of lactulose (4-O- $\beta$-galactopyranosylfructose) by $\beta$-galactosidase. Acta Pharm Fennicae $87: 75-83$.

Vera C, Guerrero C, Illanes A. 2011. Determination of the transgalactosylation activity of Aspergillus oryzae beta-galactosidase: effect of $\mathrm{pH}$, temperature, and galactose and glucose concentrations. Carbohyd Res 346:745-52.

Vogt JA, Ishii-Schrade KB, Pencharz PB, Jones PJ, Wolever TM. 2006. L-rhamnose and lactulose decrease serum triacylglycerols and their rate of synthesis, but not affect serum cholesterol concentration in men. J Nutr 136:2160-6.

Wang H, Yang R, Jiang X, Hua X, Zhao W, Zhang W, Chen X. 2014. Expression and characterization of two b-galactosidases from Klebsiella pneumoiae 285 in Escherichia coli and their application in the enzymatic synthesis of lactulose and 1-lactulose. Z Naturforsch C 69:479-87.

Wang M, Yang R, Hua X, Shen Q, Zhang W, Zhao W. 2015. Lactulose production from lactose by recombinant cellobiose 2-epimerase in permeabilised Escherichia coli cells. Intl J Food Sci Tech 50:1625-31. Woudenberg-van Oosterom M, van Belle HJA, van Rantwijk F, Sheldon RA. 1998. Immobilised b-galactosidase and their use in galactoside synthesis. J Mol Catal A-Chem 134:267-74.

Yuan T, Yang P, Wang Y, Meng K, Luo H, Zhang W, Wu N, Fan Y, Yao B. 2008. Heterologous expression of a gene encoding a thermostable $\beta$-galactosidase from Alicyclobacillus acidocaldarius. Biotechnol Lett 30:343-8.

Zokaee F, Kaghazchi T, Zare A, Soleimani M. 2002. Isomerization of lactose to lactulose-study and comparison of three catalytic systems. Process Biochem 37:629-35.

Zvonicek V, Sevcik P, Votava M, Ondrovcik P, Zabranska S, Sas I, Kraus R, Sramek V. 2001. The effect of lactulose in prevention of ventilator associated pneumonia (VAP). Crit Care 5:S19-20. 